\title{
Foreign Investment, Regulatory Arbitrage, and the Risk of U.S. Banking Organizations
}

\author{
W. Scott Frame, Atanas Mihov, and Leandro Sanz*
}

\begin{abstract}
This study investigates the implications of cross-country differences in banking regulation and supervision for the international subsidiary locations and risk of U.S. bank holding companies (BHCs). We find that BHCs are more likely to operate subsidiaries in countries with weaker regulation and supervision and that such location decisions are associated with elevated BHC risk and higher contribution to systemic risk. The quality of BHCs' internal controls and risk management plays an important role in these location choices and risk outcomes. Overall, our study suggests that U.S. banking organizations engage in cross-country regulatory arbitrage, with potentially adverse consequences.
\end{abstract}

\section{Introduction}

The international banking system has evolved into an increasingly important cross-border conduit for the transfer of capital (McGuire and Tarashev (2008)).

*Frame, scott.frame@dal.frb.org, Federal Reserve Bank of Dallas; Mihov (corresponding author), atanas.mihov@rich.frb.org, Federal Reserve Bank of Richmond; and Sanz, leandro.sanz@rich.frb.org, Federal Reserve Bank of Richmond. The authors thank David Becher, Thorsten Beck, Allen Berger, Mitchell Berlin (discussant), Giacomo Calzolari (discussant), Mark Carey (discussant), Eugeneio Cerutti, Stijn Claessens, Ricardo Correa, Ibrahim Ergen, Jean-Pierre Fenech (discussant), Jeffrey Gerlach, Linda Goldberg, Neeltje van Horen (discussant), Joel Houston (the referee), Andrew Karolyi, Nada Mora, Ned Prescott, John Sedunov (discussant), Marti Subrahmanyam, Alvaro Taboada (discussant), Judit Temesvary, Barry Williams, and Laurent Weill (discussant) for valuable comments and suggestions. They also thank seminar and conference participants at the Bank of Finland, the Bank of France, the Reserve Bank of Australia, and Sveriges Riksbank; the 2016 International Conference on Financial Cycles, Systemic Risk, Interconnectedness, and Policy Options for Resilience; the 2016 Federal Deposit Insurance Corporation (FDIC)/Journal of Financial Services Research (JFSR) 16th Annual Bank Research Conference; the 2016 Conference on Financial Intermediation in Emerging Markets; the 2017 Allied Social Sciences Associations (ASSA) Annual Meeting; the 2017 Fixed Income and Financial Institutions Conference; the 2017 Northern Finance Association Annual Meeting; and the 2017 Ninth Baffi Carefin International Banking Conference for valuable comments and suggestions. They also thank Tobias Adrian and Markus Brunnermeier for providing bank holding company (BHC) risk data and Andrew Ellul and Vijay Yerramilli for providing BHC risk management quality data. All remaining errors are the authors' alone. The views expressed in this article do not necessarily reflect the position of the Federal Reserve Bank of Dallas, the Federal Reserve Bank of Richmond, or the Federal Reserve System. 
According to the Bank for International Settlements (BIS), foreign claims of international banking organizations surged 15-fold, from \$1.9 to \$27.9 trillion, between 1995 and 2013. Foreign claims associated exclusively with U.S. banking organizations rose in tandem over this period and stood at \$3.2 trillion in 2013. Figure 1 illustrates these trends.

\section{FIGURE 1}

\section{Worldwide and U.S. Bank Foreign Claims}

Figure 1 shows worldwide and U.S. foreign claims (USD trillions) during the period 1995-2013. Foreign claims are defined as the sum of cross-border and local claims. Cross-border claims are direct claims of domestic banks or their foreign affiliates in third countries on foreign entities and individuals. Local claims are claims of domestic banks' foreign affiliates on local entities and individuals. The data are from the Bank for International Settlements (BIS) consolidated banking statistics on an immediate counterparty basis.

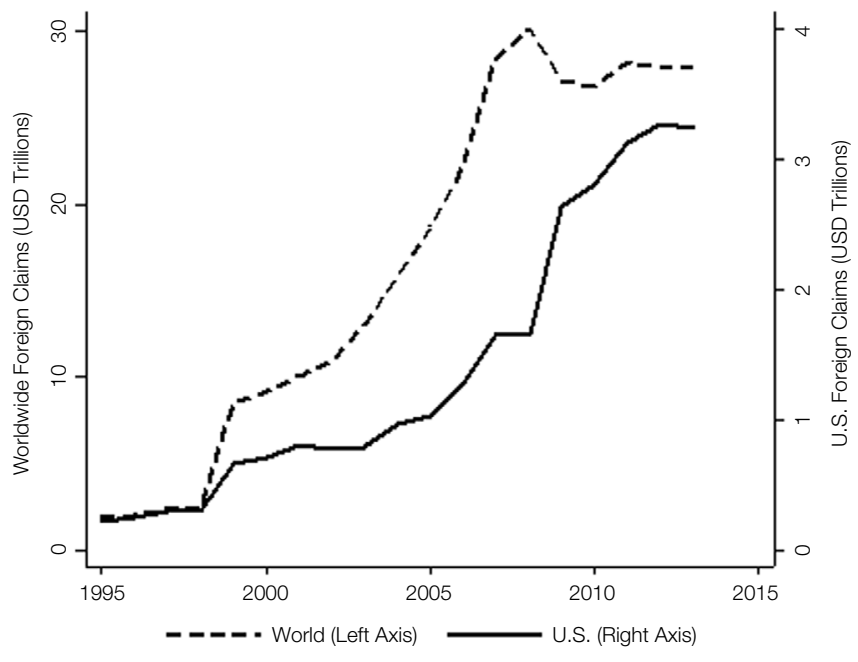

The rapid growth of international banking can be broadly attributed to technological advancements, as well as greater capital market liberalization and economic integration (e.g., Focarelli and Pozzolo (2005)). The distribution of international banking flows has also been found to vary significantly depending on host-country economic and institutional characteristics, including the stringency of banking regulation and supervision (Houston, Lin, and Ma (2012)). The global financial crisis highlighted the importance of international financial linkages within and between global banking organizations and also exposed limitations associated with material cross-border differences in regulatory environments. Since that time, significant policy attention has been paid to improved international coordination in setting banking regulatory and supervisory standards through the Financial Stability Board (FSB) and Basel Committee on Banking Supervision (BCBS). ${ }^{1}$

\footnotetext{
${ }^{1}$ In the extreme, one might imagine centralizing international banking regulation (rather than seeking to coordinate on broad principles). But such an approach could be costly and necessarily limit the flexibility in policy design tailored to the banking sector of individual countries (Morrison and White (2009)).
} 
An important issue for policy makers is regulatory arbitrage, or the situation where countries with weaker regulatory environments attract capital flows from banking organizations domiciled in countries with stricter rules (e.g., Tarullo (2010)). ${ }^{2}$ Different perspectives on this form of regulatory arbitrage have emerged. On the one hand, this strategy may enable banking organizations to evade costly regulation in a manner that improves allocative efficiency and ultimately enhances global economic growth. On the other hand, such regulatory arbitrage may be viewed as a "race to the bottom" that allows banking organizations to engage in excessive risk taking (Barth, Caprio, and Levine (2004)) and potentially heightens systemic risk at home. Hence, an accounting of regulatory arbitrage activity and its risk implications is an important ingredient for calibrating the design of international regulatory and supervisory standards.

This article explores these issues by studying whether cross-country differences in banking regulatory environments are associated with the subsidiary location choices and risk profiles of U.S. bank holding companies (BHCs). We focus on subsidiaries as the mechanism for regulatory arbitrage because these are separate legal entities incorporated in host countries and subject to those nations' regulatory regimes (Focarelli and Pozzolo (2005), Fiechter, Otker-Robe, Ilyina, Hsu, Santos, and Surti (2011), and Ongena, Popov, and Udell (2013)). By contrast, direct exposures or those through foreign branches are subject to home-country regulations.

Using supervisory information about the international structure of U.S. BHCs from 1995 to 2013, we first investigate whether cross-country differences in regulatory stringency influence the international subsidiary locations of these institutions. Consistent with regulatory arbitrage, we find that U.S. BHCs are more likely to have subsidiaries in countries with more lax regulatory environments (defined as fewer activities restrictions, less stringent capital requirements, and weaker supervision). ${ }^{3}$ On average, we estimate that a 1-standard-deviation decrease in the stringency of regulation and supervision corresponds to an increase of 1.2 percentage points in the probability of a BHC having a subsidiary in a given country, which is economically significant given that the unconditional probability of subsidiary presence in our sample is 7.0 percentage points. ${ }^{4}$ We further show that this statistically and economically significant finding is robust to a variety of instrumental variable (IV) strategies. In addition, we explore the role of BHC riskmanagement functions and find that institutions with stronger risk management

\footnotetext{
${ }^{2}$ Strauss-Kahn (2009) notes that "[o]ne of the lessons of the crisis is that we must avoid regulatory arbitrage. Key aspects of prudential regulations must be applied consistently across countries and across financial activities. This is especially important today, as the road to a safer future involves strengthened financial regulation and supervision, not only of cross-border institutions but also of cross-border markets. This will only work if all countries sign on and take ownership of the initiative, and resist the temptation to offer loopholes."

${ }^{3}$ Our study leverages the global banking regulation database presented by Barth, Caprio, and Levine (2013), which builds on 4 surveys sponsored by the World Bank (released in 2001, 2003, 2007, and 2011). The data set provides information on measures of bank regulation and supervision in 180 countries over the period 1999-2011. See Section III for details on the construction of variables.

${ }^{4}$ Host-country regulation and supervision stringency is a relevant location factor for both traditional commercial banking subsidiaries and nontraditional subsidiaries (e.g., those engaging in securities, insurance, asset management, or real estate activities). See the Supplementary Material for more details.
} 
are more likely to engage in regulatory arbitrage. This result, which could stem from BHCs' choices or supervisory limitations, may reduce some of the concerns about potential risk-related externalities associated with regulatory arbitrage.

We then directly investigate the risk implications of U.S. BHCs' foreign subsidiary locations. We find that BHCs with subsidiaries in countries with weaker regulatory regimes are riskier and also contribute more to systemic risk in the United States. Specifically, on average, a 1-standard-deviation decrease in the stringency of regulation and supervision of the countries where BHCs operate subsidiaries increases the risk measures VAR and $\triangle$ COVAR by $11.8 \%$ and $9.8 \%$ (relative to the mean), respectively. We also find that BHC risk-management quality plays a critical role in both individual and systemic risk outcomes because the link between weaker foreign regulatory environments and increased risk is primarily driven by institutions with weak risk management. Overall, consistent with the "race to the bottom" interpretation, our evidence suggests that regulatory arbitrage has potentially adverse consequences. However, we also find an important role for BHC risk-management systems in limiting the heightened risks associated with operating subsidiaries in less regulated markets.

Our study contributes to several research streams. The first is an emerging literature examining the relationship between international banking activity and cross-country differences in banking regulation and supervision that focuses on the issue of regulatory arbitrage. Houston et al. (2012) examine the extent to which cross-country differences in regulatory environments are related to international bank flows and find evidence consistent with regulatory arbitrage. Ongena et al. (2013) provide evidence that European banking regulation affects multinational banks' lending practices insofar as banks with more stringent domestic regulatory regimes lower lending standards and make riskier loans abroad. Karolyi and Taboada (2015) show that cross-border bank acquisition flows usually involve acquirers from countries with stronger regulatory regimes than their targets, and they find that target and aggregate abnormal returns around deal announcements are positive and larger when acquirers come from stricter regulatory environments. ${ }^{5}$ Karolyi, Sedunov, and Taboada (2016) find that cross-border bank flows are associated with lower systemic risk and improved financial stability in recipient countries, with results particularly strong in countries with weak regulatory quality. Temesvary (2018) shows that U.S. banks lend less to countries with stricter bank regulations and that banks that do so are more profitable in their foreign activities.

Similar to Temesvary (2018), and unlike the rest of the literature in this area, our research analyzes the foreign activities of U.S. BHCs, some of the very institutions that played a central role in the 2008-2009 global financial crisis. However, unlike that article, we focus on foreign subsidiary locations because these entities are principally subject to host-country regulatory regimes, whereas branches and direct cross-border exposures fall under the U.S. regulatory system. ${ }^{6}$

\footnotetext{
${ }^{5}$ For other recent articles that link regulatory issues to cross-border merger activity, see Hagendorff, Collins, and Keasey (2008) and Carbo-Valderde, Kane, and Rodriguez-Fernandez (2012).

${ }^{6}$ In additional analysis, we find a relatively weak and fragile empirical relation between regulatory stringency in host countries and BHC branch locations, driven by a single host country: Great Britain. This finding is consistent with Goldberg and Saunders (1980), who argue that Great Britain played a
} 
By examining U.S. BHCs' subsidiary locations, we provide new direct evidence on the extent to which global banking organizations engage in regulatory arbitrage. In addition, we provide unique evidence on the association between foreign regulatory environments and U.S. BHCs' risk-management quality with regard to subsidiary locations. Crucially, we also document a strong relation between BHCs' subsidiary locations, regulatory stringency, and BHC risk profiles, highlighting a channel for the transmission of risk to the U.S. financial system.

Our article also contributes to the literature on the determinants of global banking activity. Goldberg and Saunders (1980) test various hypotheses on the drivers of U.S. bank expansion abroad, with particular emphasis on Great Britain. Miller and Parkhe (1998) examine U.S. banks' patterns of foreign operations, including their levels of banking services and choice of organizational forms in host countries. Buch (2003) finds that information cost and regulation are correlated with the international asset choices of banks in the European Union. Focarelli and Pozzolo (2005) examine the importance of institutional characteristics and market profitability for bank location choice. Mian (2006) studies how cultural and geographical distance limit foreign lending in poor economies. Sengupta (2007) examines interactions between foreign entry and bank competition and discusses lending patterns by foreign banks. Complementary to such literature, we find that cross-country differences in banking regulation and supervision are an important determinant of the foreign subsidiary locations of U.S. BHCs.

Finally, although an abundance of research examines the determinants of bank risk, most studies largely ignore the effects of internationalization (Beltratti and Stulz (2012)). Amihud, DeLong, and Saunders (2002) examine the effects of cross-border mergers and report that, on average, neither the total risk nor the systematic risk of acquiring banks changes significantly. Buch, Koch, and Koetter (2013) document a weak link between internationalization and German bank risk. By contrast, Berger, Ghoul, Guedhami, and Roman (2017) document a positive relation between internationalization and U.S. bank risk and suggest that this results from foreign-market-specific factors. Cetorelli and Goldberg (2011) highlight the importance of multinational banks in cross-border risk transmission and the propagation of international liquidity shocks. We extend this literature by documenting an important channel of internationalization, regulatory arbitrage, through which banking organizations may increase risk taking and contribute to the fragility of the U.S. financial system. We also show that strong risk management significantly mitigates the associated risk outcomes.

Our study is also relevant to the policy discussion around international regulatory and supervisory coordination following the global financial crisis. Our results highlight a significant drawback to a fully decentralized territorial approach to banking regulation because global banking organizations may undermine domestic rules by "importing" risks through cross-border regulatory arbitrage. Our results are thus overall consistent with the postcrisis approaches taken by the

key role as a driver of the expansion of U.S. bank branches abroad, but suggests that U.S. BHCs likely do not engage in regulatory arbitrage through foreign branch activity. See the Supplementary Material for more details. 
FSB and BCBS of enhancing international coordination to reduce material crosscountry differences in supervision and regulation.

The remainder of the article is organized as follows: Section II lays out the hypotheses for our empirical analysis. Section III describes our sample, provides variable definitions, and presents descriptive statistics. Sections IV and V present the results on BHC subsidiary locations and risk, respectively. Section VI discusses potential policy implications. Section VII concludes.

\section{Hypotheses}

Cross-country differences in regulation and supervision enable global banks to consider the stringency of foreign regulation and supervision when choosing their bases for providing financial services. Jurisdictions with a lower regulatory burden are more attractive to financial institutions. First, less strict regulation and supervision reduce compliance costs and improve operational efficiency. Second, easing regulatory constraints expands opportunities for business activities and risk taking, which allows BHCs to adjust their balance sheets and move closer to desired risk-return levels. In contrast to foreign branches and direct cross-border exposures, foreign subsidiaries are principally subject to host-country regulatory regimes and thus facilitate regulatory arbitrage across national jurisdictions. We therefore hypothesize:

Hypothesis 1. U.S. BHCs are more likely to operate subsidiaries in countries with weaker regulation and supervision.

Conditional on Hypothesis 1 holding, it is important to understand whether banking organizations exploiting cross-country differences in regulation and supervision are well equipped to manage risks in an environment conducive to greater risk taking. If banking organizations with strong abilities to identify, measure, monitor, and control risk are the ones primarily engaging in regulatory arbitrage, this might reduce concerns related to BHC risk taking. Conversely, if banking organizations with weak risk management tend to engage in regulatory arbitrage, this might elevate concerns related to $\mathrm{BHC}$ risk taking. The relation between risk-management quality at BHCs and regulatory stringency in host countries with respect to bank subsidiary locations is a priori unclear. The previous discussion suggests that jurisdictions with weak regulation and supervision should be attractive to all institutions, other things being equal. We therefore examine this relation empirically, where we test a 2-tailed hypothesis:

Hypothesis 2A. U.S. BHCs with poor risk management tend to operate subsidiaries in countries with weaker regulation and supervision.

Hypothesis $2 B$. U.S. BHCs with strong risk management tend to operate subsidiaries in countries with weaker regulation and supervision.

Conditional on Hypothesis 1 holding, one would want to understand the implications of regulatory arbitrage for BHCs' overall risk profiles and any spillover to the domestic financial system. Regulatory arbitrage can be conducive to increased risk taking in many ways, including fewer restrictions on potentially risky activities, less stringent capital requirements allowing for higher financial 
leverage, and weaker supervisory approaches to curtail risk taking. By transferring activities to less regulated jurisdictions, regulatory arbitrage can heighten BHC stand-alone risk. Moreover, given the interconnected nature of global banking organizations, regulatory arbitrage can also contribute to home-country systemic risk. This can be directly through the increased risk of U.S.-based global institutions or indirectly through increased fragility of host-country banking systems, which are "nodes" in the interconnected global financial network. We thus hypothesize:

Hypothesis 3. U.S. BHCs that operate subsidiaries in countries with weaker regulation and supervision have higher stand-alone risk and contribute more to domestic systemic risk.

Risk-management functions at global banking organizations assess the risks faced by the organizations, communicate such assessments to those who make risk-taking decisions, and manage and monitor assumed risks to ensure they are within the limits set by the banking organizations' management and boards of directors. Ellul and Yerramilli (2013) show that weak BHC risk controls and a lack of independence of risk-management functions are associated with increased risk exposures at large BHCs. At the same time, if Hypothesis 3 holds, regulatory arbitrage should present enhanced opportunities for risk taking. Consequently, we expect to see risk amplification for banking organizations with poor risk management that operate subsidiaries in countries with weak regulation and supervision:

Hypothesis 4. The risk effects of subsidiaries in countries with weaker regulation and supervision are more pronounced for U.S. BHCs with weak risk management.

\section{Data}

\section{A. Foreign Subsidiaries of U.S. BHCs}

We start our analysis by examining the international organizational structure of U.S. BHCs during the period 1995-2013. These institutions can gain foreign exposure through direct cross-border activities, branches, or subsidiaries. Foreign exposures emerging from direct cross-border activities, such as a loan to a firm based in a foreign country, are governed by the BHCs' home-country regulations. Likewise, banking activities through foreign branches, which are integrated into the BHC, are bound by home-country regulations. By contrast, foreign subsidiaries are separate legal entities that must comply with regulations in the jurisdiction where they operate (Focarelli and Pozzolo (2005), Fiechter et al. (2011), and Ongena et al. (2013)). For this reason, we study the location of U.S. BHCs' foreign subsidiaries in relation to cross-border differences in banking regulation and supervision. ${ }^{7}$

Data on the location of U.S. BHCs' foreign subsidiaries are obtained from the Federal Reserve's FR Y-10 report. Specifically, we start with the stock of

\footnotetext{
${ }^{7}$ We restrict our analysis to foreign subsidiaries associated with the following North American Industry Classification System (NAICS) industry codes: 522 (credit intermediation and related activities), 523 (securities, commodity contracts, and other financial investments), 524 (insurance carriers and related activities), 525 (funds, trusts, and other financial vehicles), 531 (real estate), and 551 (management of companies and enterprises).
} 
foreign subsidiaries as of 1995 and then record entry and exit decisions thereafter, including the establishment of de novo subsidiaries, acquisition of a controlling interest in existing institutions, and changes of those interests through mergers or divestitures. The organizational data comprise only material exposures and exclude subsidiaries that are not controlled by a BHC or not actively engaged in a business activity. ${ }^{8}$ We use these data to construct a panel data set consisting of 135 unique U.S. BHCs operating 8,194 foreign subsidiaries during the period 1995-2013.

We measure BHCs' foreign subsidiary locations with PRESSUB and $\ln (\mathrm{NSUB})$. PRESSUB is an indicator variable equal to 1 if a BHC operates at least one subsidiary in a given country during a year, and 0 otherwise. $\ln$ (NSUB) is the natural logarithm of 1 plus the number of foreign subsidiaries a BHC operates in a given country during a year. The Appendix provides definitions for these and all other variables we use in our analysis.

\section{B. Cross-Country Banking Regulation and Supervision}

We use the global banking regulation database of Barth et al. (2013) to measure banking regulation and supervision stringency across countries. ${ }^{9}$ The data build on 4 surveys sponsored by the World Bank and released in 2001 (I), 2003 (II), 2007 (III), and 2011 (IV). Because the survey data are not available yearly, we take values from Survey I for the period 1995-2001, values from Survey II for the period 2002-2005, values from Survey III for the period 2006-2009, and values from Survey IV for the period 2010-2013.

We focus on 3 dimensions of regulation and supervision: activity restrictions, capital regulation, and supervisory power. These measures are relatively broad, capture historically key macro- and micro-prudential areas of regulatory focus and tools for corrective action, and have received emphasis in prior research (Ongena et al. (2013), Karolyi and Taboada (2015)). The stringency of each dimension is measured by an index. The activity-restriction index measures the stringency of regulation regarding banks' involvement in securities, insurance, and real estate activities. The capital-regulation index measures the degree to which supervisory authorities oversee capital at risk and the initial source of funds used to capitalize a bank. The supervisory-power index measures the extent to which supervisory authorities can intervene to prevent and correct problems at financial institutions. To construct a single measure of banking regulation and supervision stringency, we extract the first principal component from activity restrictions, capital regulation, and supervisory power. To ease the exposition of results, we transform all 4 indices by subtracting each index from its maximum value so that higher values indicate weaker regulation and supervision.

\footnotetext{
${ }^{8}$ Control is defined according to the Federal Reserve's Regulation Y. In particular, a BHC controls a subsidiary if i) it owns at least $25 \%$ of the voting securities; ii) it controls the election of a majority of the directors, trustees, or general partners (or individuals exercising similar functions); or iii) has the power to exercise, directly or indirectly, a controlling influence over the management of the offspring.

${ }^{9}$ The database has also been used by other recent studies analyzing cross-country banking regulatory differences (e.g., Houston et al. (2012), Karolyi and Taboada (2015), and Karolyi et al. (2016)).
} 
Table 1 sorts the total number of distinct U.S. BHC subsidiaries into the countries where they operate (top 30 countries by representation). ${ }^{10}$ The summary statistics suggest significant heterogeneity in foreign subsidiary locations. In the top 10 countries, we encounter global financial centers such as the United Kingdom and Japan, emerging markets such as Brazil, and offshore financial centers such as Mauritius. Figure 2 presents a scatter plot of U.S. BHC subsidiary presence and regulation and supervision stringency at the country level. Here we see that, despite the heterogeneity in the locations of foreign subsidiaries, U.S. BHCs are more likely to operate subsidiaries in countries with weaker banking regulation and supervision. ${ }^{11}$

\section{TABLE 1}

\section{Country Breakdown of Foreign Subsidiary Presence}

Table 1 sorts distinct U.S. bank holding company $(\mathrm{BHC})$ subsidiaries into countries where they operate (top 30 countries by representation) during the period 1995-2013. Table 1 also shows the means of REGULATION_\&_SUPERVISION, ACTIVITY RESTRICTIONS, CAPITAL REGULATION, and SUPERVISORY POWER, which measure the stringency of a country's banking regulation and supervision. REGULATION_\&_SUPERVISION is defined as the first principal component of ACTIVITY_RESTRICTIONS, CAPITAL_REGULATION, and SUPERVISORY_POWER. ACTIVITY_RESTRICTIONS measures the stringency of a country's regulation regarding banks' involvement in securities, insurance, and real estate activities. CAPITAL_REGULATION measures the degree to which supervisory authorities in a country oversee capital at risk and the initial source of funds used to capitalize a bank. SUPERVISORY_POWER measures the extent to which supervisory authorities in a country can intervene to prevent and correct problems at financial institutions.

\begin{tabular}{|c|c|c|c|c|c|}
\hline Country & $\begin{array}{c}\text { No. of } \\
\text { Subsidiaries } \\
\end{array}$ & $\begin{array}{l}\text { REGULATION_\&_} \\
\text { SUPERVISION } \\
\end{array}$ & $\begin{array}{c}\text { ACTIVITY } \\
\text { RESTRICTIONS } \\
\end{array}$ & $\begin{array}{l}\text { CAPITAL_- } \\
\text { REGULATION }\end{array}$ & $\begin{array}{c}\text { SUPERVISORY_ } \\
\text { POWER } \\
\end{array}$ \\
\hline United Kingdom & 1,983 & 4.501 & 8.427 & 2.767 & 6.282 \\
\hline Luxembourg & 849 & 3.082 & 5.703 & 3.000 & 4.037 \\
\hline Australia & 763 & 3.111 & 5.321 & 2.411 & 5.000 \\
\hline Canada & 587 & 4.997 & 6.957 & 5.468 & 7.813 \\
\hline Netherlands & 572 & 4.147 & 7.388 & 2.776 & 6.164 \\
\hline Brazil & 412 & 3.907 & 8.000 & 5.000 & 3.000 \\
\hline Germany & 409 & 4.726 & 7.869 & 3.605 & 7.131 \\
\hline Hong Kong & 323 & 5.120 & 9.000 & 4.000 & 7.000 \\
\hline Mauritius & 198 & 1.369 & 2.000 & 3.000 & 2.000 \\
\hline Singapore & 190 & 2.107 & 5.000 & 2.000 & 2.000 \\
\hline France & 186 & 2.893 & 4.000 & 2.000 & 6.000 \\
\hline Argentina & 178 & 3.387 & 5.261 & 2.475 & 6.025 \\
\hline Chile & 133 & 1.567 & 2.000 & 4.000 & 2.000 \\
\hline India & 123 & 2.385 & 3.000 & 1.000 & 6.000 \\
\hline Spain & 118 & 3.877 & 6.557 & 1.557 & 7.000 \\
\hline Korea, South & 115 & 3.598 & 4.195 & 2.195 & 8.203 \\
\hline Poland & 97 & 2.733 & 5.217 & 3.643 & 2.852 \\
\hline Belgium & 95 & 3.295 & 6.212 & 2.485 & 4.606 \\
\hline Italy & 85 & 3.381 & 4.605 & 4.395 & 5.369 \\
\hline Malaysia & 75 & 2.317 & 4.000 & 5.724 & 1.224 \\
\hline Switzerland & 75 & 4.374 & 9.000 & 3.000 & 5.000 \\
\hline New Zealand & 62 & 5.286 & 7.000 & 8.000 & 7.000 \\
\hline Colombia & 41 & 2.950 & 3.455 & 3.273 & 5.909 \\
\hline Russia & 41 & 4.525 & 6.447 & 3.000 & 8.447 \\
\hline Philippines & 40 & 3.553 & 7.000 & 2.000 & 5.000 \\
\hline Thailand & 38 & 1.598 & 4.000 & 1.000 & 2.000 \\
\hline Uruguay & 36 & 1.841 & 3.456 & 2.456 & 2.456 \\
\hline South Africa & 32 & 5.207 & 6.000 & 5.000 & 10.000 \\
\hline Venezuela & 32 & 2.705 & 4.020 & 5.529 & 2.755 \\
\hline Cyprus & 30 & 2.852 & 4.724 & 1.579 & 5.330 \\
\hline Others & 276 & 2.882 & 4.411 & 3.124 & 4.685 \\
\hline Mean & - & 3.105 & 4.911 & 3.193 & 4.880 \\
\hline Total & 8,194 & - & - & - & - \\
\hline
\end{tabular}

${ }^{10}$ Due to data availability issues, we exclude the Cayman Islands, one of the largest subsidiary destination countries for U.S. BHCs, from our sample. To the extent that the Cayman Islands maintains a relatively lax regulatory environment, this exclusion should only weaken our results.

${ }^{11}$ In unreported tests, we confirm that our results are robust to excluding the 3 countries with the highest concentration of U.S. BHC subsidiaries in our sample: Canada, the United Kingdom, and Hong Kong. 
FIGURE 2

\section{Subsidiary Presence and Foreign Regulation and Supervision Stringency}

Figure 2 presents a scatter plot with a linear fit of the relation between U.S. bank holding company (BHC) subsidiary presence and foreign regulation and supervision stringency at the country level. The sample comprises 135 U.S. BHCS during the period 1995-2013 with subsidiaries in 69 countries. PRESSUB is an indicator variable that equals 1 if a BHC reports having foreign subsidiaries in a given country during a year, and 0 otherwise. REGULATION_\&_SUPERVISION measures the stringency of a country's banking regulation and supervision. It is defined as the first principal component of ACTIVITY_RESTRICTIONS, CAPITAL_REGULATION, and SUPERVISORY_POWER. ACTIVITY_RESTRICTIONS measures the stringency of a country's regulation regarding banks' involvement in securities, insurance, and real estate activities. CAPITAL_REGULATION measures the degree to which supervisory authorities in a country oversee capital at risk and the initial source of funds used to capitalize a bank. SUPERVISORY_POWER measures the extent to which supervisory authorities in a country can intervene to prevent and correct problems at financial institutions. Higher values indicate weaker regulation and supervision stringency. Country nomenclature for the top and bottom 10 countries in terms of REGULATION_\&_SUPERVISION is as follows: Austria (AUS), Canada (CAN), Switzerland (CHE), Chile (CHL), Germany (DEU), United Kingdom (GBR), Guatemala (GTM), Hong Kong (HKG), Indonesia (IDN), Morocco (MAR), Mauritius (MUS), Nicaragua (NIC), New Zealand (NZL), Pakistan (PAK), Russian Federation (RUS), Thailand (THA), Turkey (TUR), Uganda (UGA), Uruguay (URY), and South Africa (ZAF).

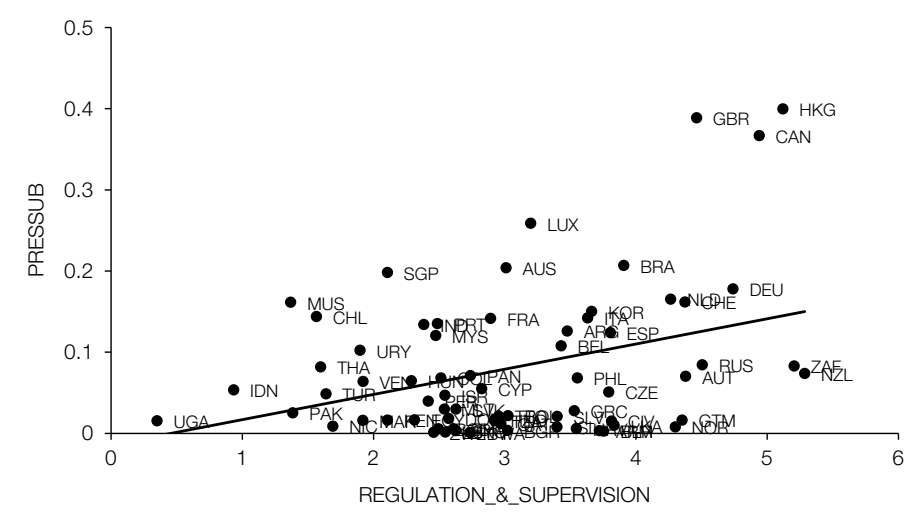

Table 1 also shows that banking regulation and supervision stringency varies across the different dimensions within countries, suggesting that the indices capture distinct aspects of regulatory intensity. For instance, the United Kingdom maintains relatively strict capital requirements but relatively weak activity restrictions over the sample period.

\section{Other Determinants of BHC Subsidiary Locations}

A number of country-level factors have been previously shown to affect the foreign locations of BHC operations. In our multivariate regressions, we control for a country's size of economic activity using the real gross domestic product (GDP) published by the World Bank. In addition, we control for real GDP per capita and real GDP growth as measures of economic development and economic growth, respectively. Cross-border banking activities may also be related to the degree of country-output synchronization (Kalemli-Ozcan, Papaioannou, and Peydró (2013)). Hence, we include the $R^{2}$ of regressions of U.S. GDP growth on a given country's GDP growth. Likewise, cross-border activities may depend on bilateral trade between countries (Goldberg and Saunders (1980)), which we control for using the maximum of bilateral imports and exports between the United States and a given country. Bilateral imports (exports) are calculated as the total value of imports (exports) by a given country from (to) the United States as a proportion of total imports by that country from (to) the rest of the world. Data on 
bilateral trade are obtained from the International Monetary Fund (IMF) Direction of Trade Statistics.

Lin, Mihov, Sanz, and Stoyanova (2019) show that country institutional quality affects foreign direct investment. Therefore, we include the average of 6 country governance indicators from Kaufman, Kraay, and Mastruzzi (2009): control of corruption, rule of law, regulatory quality, government effectiveness, political stability, and voice and accountability. We also create an indicator for offshore financial centers, which have been found to host more cross-border assets of financial companies (Rose and Spiegel (2007)). Creditor and borrower rights have also been shown to be important for cross-border credit provision (e.g., Djankov, Caralee, and Shleifer (2007)). We thus include an index from the World Bank of borrower and lender protection by collateral and bankruptcy laws. ${ }^{12}$ BHCs' foreign subsidiary locations may also be related to capital market development, the composition of the banking sector, and banking-sector profitability (Focarelli and Pozzolo (2005)). Thus, we also control for the host country's ratio of private credit to GDP, banking-sector concentration, and banking-sector return on equity using measures from Barth et al. (2013) and the Global Financial Development Database. $^{13}$

Finally, cross-border banking flows may also be influenced by the physical and cultural distance between the home and host markets. Therefore, we include a measure of geographic distance and indicator variables for countries that have English as their official language and those that share a border with the United States (Mayer and Zignago (2011)).

\section{Summary Statistics}

Table 2 reports summary statistics for all previously described variables (Panel A) and pairwise correlations between our location and regulatorystringency variables (Panel B). PRESSUB has a mean of 0.070 , which indicates that $7.0 \%$ of the BHCs in our sample report having foreign subsidiaries in a country-year pair. The unconditional sample mean of NSUB, the number of subsidiaries a BHC has in a country during a year, is 0.5 . This translates into approximately seven subsidiaries per country-year based on observations that reflect BHC subsidiary presence. The sample means of ACTIVITY_RESTRICTIONS, CAPITAL_REGULATION, and SUPERVISORY_POWER are 4.6, 3.4, and 5.1, respectively. For comparison, average index values for the United States across the same indices are 3.4, 2.3, and 2.7, respectively. Thus, the United States tends to have more stringent banking regulation and supervision relative to the average country in our sample.

The pairwise correlations indicate that PRESSUB and $\ln$ (NSUB) are positively correlated with ACTIVITY_RESTRICTIONS, CAPITAL_REGULATION, and SUPERVISORY_POWER, as well as our composite measure

\footnotetext{
${ }^{12}$ Borrower and creditor rights index data start in 2004. We carry back the earliest observable value for each country to the period 1995-2003. Our results are robust to excluding the 1995-2003 subperiod from our analysis.

${ }^{13}$ Data for banking-sector return on equity start in 1999. We carry back the earliest observable value for each country to the period 1995-1998. Our results are robust to excluding the 1995-1998 subperiod from our analysis.
} 
TABLE 2

Summary Statistics and Variable Correlations

Table 2 presents summary statistics (Panel A) and pairwise correlations (Panel B) of the main variables in our analysis. The sample includes a panel of 43,739 bank holding company (BHC)-year-subsidiary country observations during the period 1995-2013 of 135 U.S. BHCs. p-values are reported in parentheses. ${ }^{*}$, ${ }^{* *}$, and ${ }^{* * *}$ indicate significance at the $10 \%$, $5 \%$, and $1 \%$ levels, respectively. Detailed definitions of all variables are presented in the Appendix.

Panel A. Summary Statistics

\begin{tabular}{|c|c|c|c|c|c|c|c|}
\hline \multicolumn{3}{|c|}{ Variable } & Mean & Std. Dev. & Minimum & Maximum & No. of Obs. \\
\hline \multicolumn{3}{|l|}{ PRESSUB } & 0.070 & 0.255 & 0 & 1 & 43,739 \\
\hline & & & 0.100 & 0.437 & 0 & 5.468 & 43,739 \\
\hline \multicolumn{3}{|c|}{$\begin{array}{l}\text { In(NSUB) } \\
\text { REGULATION \& SUPERVISION }\end{array}$} & 3.124 & 1.136 & 0 & 6.027 & 43,739 \\
\hline \multicolumn{3}{|c|}{ ACTIVITY_RESTRICTIONS } & 4.634 & 2.021 & 0 & 9 & 43,739 \\
\hline \multicolumn{3}{|c|}{ CAPITAL_REGULATION } & 3.429 & 1.798 & 0 & 8 & 43,739 \\
\hline \multicolumn{3}{|c|}{ SUPERVISORY_POWER } & 5.093 & 2.430 & 0 & 12 & 43,739 \\
\hline \multicolumn{3}{|c|}{$\ln (G D P)$} & 24.441 & 2.210 & 19.249 & 28.918 & 43,739 \\
\hline \multirow{2}{*}{\multicolumn{3}{|c|}{ GDPG }} & 0.008 & 0.130 & -0.895 & 0.383 & 43,739 \\
\hline & & & 0.263 & 0.251 & 0 & 1 & 43,739 \\
\hline \multicolumn{3}{|c|}{ In(GDPPC) } & 8.446 & 1.565 & 4.709 & 11.477 & 43,739 \\
\hline \multirow{2}{*}{\multicolumn{3}{|c|}{$\begin{array}{l}\text { BILATERAL_TRADE } \\
\text { COUNY_GYVRANCE }\end{array}$}} & 0.564 & 0.800 & 0 & 5.566 & 43,739 \\
\hline & \multicolumn{2}{|c|}{ COUNTRY_GOVERNANCE } & 0.231 & 0.827 & -1.544 & 1.910 & 43,739 \\
\hline \multirow{2}{*}{\multicolumn{3}{|c|}{$\begin{array}{l}\text { CREDIT_TO__GDP } \\
\text { BORROWER \& CREDITOR RIGHTS }\end{array}$}} & 0.589 & 0.514 & 0.010 & 2.846 & 43,739 \\
\hline & & & 5.575 & 2.425 & 0 & 12 & 43,739 \\
\hline \multicolumn{3}{|c|}{ BANKING CONCENTRATION } & 0.692 & 0.179 & 0.120 & 1 & 43,739 \\
\hline \multicolumn{3}{|c|}{ BANKING_SECTOR_PROFITABILITY } & 0.120 & 0.130 & -0.544 & 0.595 & 43,739 \\
\hline \multicolumn{3}{|c|}{ OFFSHORE_FINANCIAL_CENTER } & 0.121 & 0.326 & 0 & 1 & 43,739 \\
\hline \multicolumn{3}{|c|}{ CONTIGUOÜS } & 0.025 & 0.157 & 0 & 1 & 43,739 \\
\hline \multicolumn{3}{|c|}{ COMMON_LANGUAGE } & 0.258 & 0.438 & 0 & 1 & 43,739 \\
\hline \multicolumn{3}{|c|}{ In(DISTANCE) } & 8.874 & 0.598 & 6.307 & 9.692 & 43,739 \\
\hline \multicolumn{8}{|c|}{ Panel B. Correlations } \\
\hline & PRESSUB & $\ln (\mathrm{NSUB})$ & \multicolumn{2}{|c|}{$\begin{array}{l}\text { REGULATION_\& } \\
\text { SUPERVISION }\end{array}$} & $\begin{array}{l}\text { ACTIVITY } \\
\text { RESTRICTIONS }\end{array}$ & $\begin{array}{l}\text { CAPITAL } \\
\text { REGULATION }\end{array}$ & $\begin{array}{l}\text { SUPERVISORY } \\
\text { POWER }\end{array}$ \\
\hline PRESSUB & 1.000 & & & & & & \\
\hline $\ln (\mathrm{NSUB})$ & $\begin{array}{l}0.836^{\star * \star} \\
(0.000)\end{array}$ & 1.000 & & & & & \\
\hline $\begin{array}{l}\text { REGULATION_\& } \\
\text { SUPERVISION }\end{array}$ & $\begin{array}{l}0.116^{* * *} \\
(0.000)\end{array}$ & $\begin{array}{l}0.098^{* * *} \\
(0.000)\end{array}$ & & & & & \\
\hline $\begin{array}{l}\text { ACTIVITY } \\
\text { RESTRICTIONS }\end{array}$ & $\begin{array}{l}0.153^{\star * *} \\
(0.000)\end{array}$ & $\begin{array}{l}0.144^{* * *} \\
(0.000)\end{array}$ & & & 1.000 & & \\
\hline $\begin{array}{l}\text { CAPITAL_- } \\
\text { REGULATION }\end{array}$ & $\begin{array}{l}0.036^{\star * *} \\
(0.000)\end{array}$ & $\begin{array}{l}0.027^{\star * *} \\
(0.000)\end{array}$ & & & $\begin{array}{l}0.143^{\star * *} \\
(0.000)\end{array}$ & 1.000 & \\
\hline $\begin{array}{l}\text { SUPERVISORY } \\
\text { POWER }\end{array}$ & $\begin{array}{l}0.053^{\star * *} \\
(0.000)\end{array}$ & $\begin{array}{l}0.040^{* * *} \\
(0.000)\end{array}$ & & & $\begin{array}{l}0.254^{* * *} \\
(0.000)\end{array}$ & $\begin{array}{l}0.135^{\star * \star} \\
(0.000)\end{array}$ & 1.000 \\
\hline
\end{tabular}

REGULATION_\&_SUPERVISION. Such correlation evidence is visually confirmed in Figure 3, which graphs the total number of foreign subsidiaries and the number of foreign subsidiaries per BHC in each survey year for countries above and below the median of REGULATION_\&_SUPERVISION. U.S. BHCs tend to locate proportionately more foreign subsidiaries in countries with relatively weaker regulation and supervision.

\section{Subsidiary Locations}

\section{A. Subsidiary Locations and Regulatory Stringency}

We test our hypothesized relation between U.S. BHCs' foreign subsidiary locations and host countries' banking regulation and supervision using the 
FIGURE 3

\section{Subsidiaries and Foreign Regulation and Supervision Stringency}

Figure 3 shows the total number of foreign subsidiaries for all bank holding companies (BHCs) (Graph A) in our sample and the number of foreign subsidiaries per BHC (Graph B) for countries with above- and below-median regulation and supervision stringency. The sample comprises 135 U.S. BHCs during the period 1995-2013 with subsidiaries in 69 countries. Subsidiary counts are averaged within each survey of the Barth et al. (2013) global banking regulation database for each BHC. REGULATION \& SUPERVISION measures the stringency of a country's banking regulation and supervision. It is defined as the first principal component of ACTIVITY_RESTRICTIONS, CAPITAL_REGULATION, and SUPERVISORY_POWER. ACTIVITY_RESTRICTIONS measures the stringency of a country's regulation regarding banks' involvement in securities, insurance, and real estate activities. CAPITAL_REGULATION measures the degree to which supervisory authorities in a country oversee capital at risk and the initial source of funds used to capitalize a bank. SUPERVISORY_POWER measures the extent to which supervisory authorities in a country can intervene to prevent and correct problems at financial institutions. Higher values indicate weaker regulation and supervision stringency.
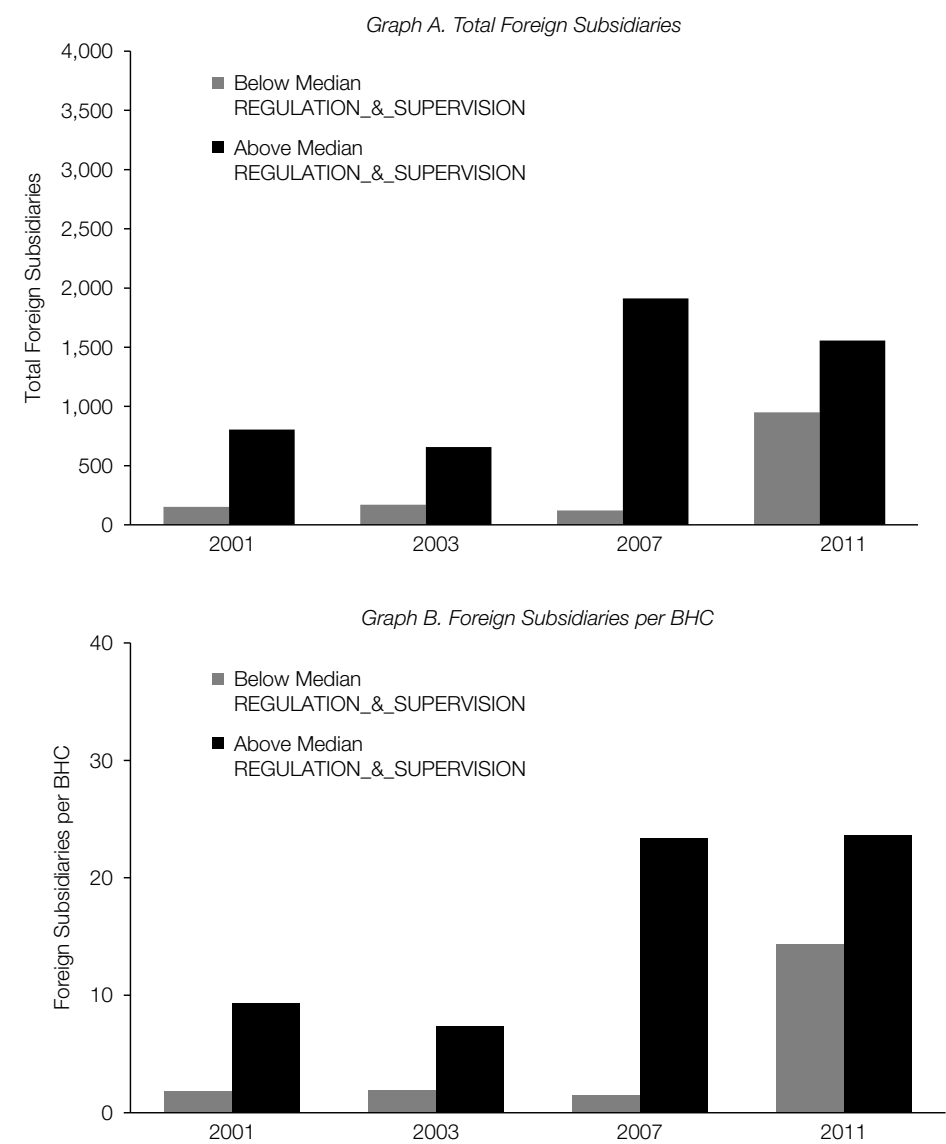

following specification:

$$
\begin{aligned}
Y_{i, j, t}= & \alpha_{i, t}+\beta \times \text { REGULATION_\&_SUPERVISION } \\
& +\delta X_{j, t-1}+\epsilon_{i, j, t},
\end{aligned}
$$

where $i$ indexes BHCs, $j$ indexes countries, and $t$ indexes years. The dependent variable is either PRESSUB or $\ln (\mathrm{NSUB})$. PRESSUB PRj, $_{i, t}$ is a binary variable that equals 1 if $\mathrm{BHC} i$ operates at least one foreign subsidiary in country $j$ at year $t$, and 0 otherwise. $\ln (\mathrm{NSUB})_{i, j, t}$ is the 
natural logarithm of 1 plus the number of subsidiaries BHC $i$ operates in country $j$ at year $t$. REGULATION_\&_SUPERVISION ${ }_{j, t-1}$ measures country overall regulation and supervision stringency and is defined as the first principal component of ACTIVITY_RESTRICTIONS, CAPITAL_REGULATION, and SUPERVISORY_POWER. We also estimate analogous specifications where we replace the composite measure with each of the underlying indices. The vector $X_{j, t-1}$ contains country-level controls. $\alpha_{i, t}$ denotes BHC $\times$ year fixed effects, which absorb unobservable time-invariant and time-varying bank characteristics that might otherwise conflate the analysis. To assuage information-availability concerns, we lag all independent variables by 1 year. Estimation is done by ordinary least squares (OLS), with error terms clustered at the BHC $\times$ country level. ${ }^{14}$ Table 3 presents the results.

PRESSUB and REGULATION_\&_SUPERVISION are positively related, indicating that a BHC is more likely to operate foreign subsidiaries in countries with weaker banking regulation and supervision. Based on the specification in column 1 of Table 3, a 1-standard-deviation increase in REGULATION_\&_SUPERVISION is associated with a 1.2-percentage-point increase in the likelihood of subsidiary presence on average. Given that the unconditional mean of BHC subsidiary presence is 7.0 percentage points in our data set, the magnitude of the estimated coefficient is not trivial. Similarly, in column 5, we find a positive relationship between $\ln$ (NSUB) and REGULATION_\&_SUPERVISION. Not only are BHCs more likely to operate foreign subsidiaries in countries with weaker banking regulation and supervision, but they also tend to operate more subsidiaries there. The estimated coefficient suggests that a 1-standard-deviation increase in REGULATION_\&_SUPERVISION is associated with a $1.9 \%$ increase in the number of subsidiaries a BHC operates in a country during a given year.

REGULATION_\&_SUPERVISION incorporates 3 distinct dimensions of regulatory stringency: ACTIVITY_RESTRICTIONS, CAPITAL_ REGULATION, and SUPERVISORY_POWER. Although these dimensions may be correlated within a given country, each potentially affects U.S. BHCs' foreign subsidiary locations to a different extent. So, we examine the relationship between BHC subsidiary locations and these individual components separately. We find that all 3 dimensions of a country's banking regulatory environment are important. A BHC is more likely to be present and operate more foreign subsidiaries in countries with weaker banking-activity restrictions, lower capital standards, and lighter supervision. Based on the specifications in columns 2-4 of Table 3, a 1-standard-deviation increase in ACTIVITY_RESTRICTIONS, CAPITAL_REGULATION, and SUPERVISORY_POWER is associated with average increases in the likelihood of subsidiary presence in a given country of $1.2,0.5$, and 0.7 percentage points, respectively. Likewise, results in columns 6-8 suggest that a 1-standard-deviation increase in such indices is associated with

\footnotetext{
${ }^{14}$ We employ a linear probability model specification to avoid the incidental parameter problem as a result of including a large number of fixed effects in a binary response model. As a robustness check, we estimate a conditional fixed-effects logit model for PRESSUB and a Poisson pseudo maximum likelihood (PPML) model for NSUB. In each case, we confirm our baseline results.
} 
TABLE 3

Subsidiary Locations and Foreign Regulation and Supervision Stringency

Table 3 reports coefficient estimates from panel regressions of U.S. bank holding company (BHC) subsidiary locations on foreign banking regulation and supervision stringency and control variables. The sample is a panel of $43,739 \mathrm{BHC}-$ year-subsidiary country observations during the period 1995-2013 of 135 U.S. BHCs. PRESSUB is an indicator variable that equals 1 if a BHC reports having foreign subsidiaries in a given country during a year, and 0 otherwise. In(NSUB) is the natural logarithm of 1 plus the total number of subsidiaries a BHC has in a given country during a year. REGULATION_\&_SUPERVISION, ACTIVITY_RESTRICTIONS, CAPITAL_REGULATION, and SUPERVISORY_POWER measure the stringency of a country's banking regulation and supervision. REGULATION \& SUPERVISION is defined as the first principal component of ACTIVITY_RESTRICTIONS, CAPITAL_REGULATION, and SUPERVISORY_POWER. ACTIVITY_RESTRICTIONS measures the stringency of a country's regulation regarding banks' involvement in securities, insurance, and real estate activities. CAPITAL_REGULATION measures the degree to which supervisory authorities in a country oversee capital at risk and the initial source of funds used to capitalize a bank. SUPERVISORY_POWER measures the extent to which supervisory authorities in a country can intervene to prevent and correct problems at financial institutions. Detailed definitions of all variables are presented in the Appendix. We include BHC $\times$ year fixed effects and use robust standard errors clustered at the $\mathrm{BHC} \times$ country level in all specifications. $p$-values are reported in parentheses. *, **, and ${ }^{* *}$ indicate significance at the $10 \%, 5 \%$, and $1 \%$ levels, respectively.

\begin{tabular}{|c|c|c|c|c|c|c|c|c|}
\hline \multirow[b]{2}{*}{ Variable } & \multicolumn{4}{|c|}{ PRESSUB } & \multicolumn{4}{|c|}{$\ln ($ NSUB $)$} \\
\hline & 1 & 2 & 3 & 4 & 5 & 6 & 7 & 8 \\
\hline $\begin{array}{l}\text { REGULATION_\& } \\
\text { SUPERVISION }\end{array}$ & $\begin{array}{l}0.011^{\star \star *} \\
(0.000)\end{array}$ & & & & $\begin{array}{l}0.017^{\star \star \star} \\
(0.000)\end{array}$ & & & \\
\hline $\begin{array}{l}\text { ACTIVITY } \\
\text { RESTRICTIONS }\end{array}$ & & $\begin{array}{l}0.006^{\star \star *} \\
(0.000)\end{array}$ & & & & $\begin{array}{l}0.011^{* * *} \\
(0.000)\end{array}$ & & \\
\hline $\begin{array}{l}\text { CAPITAL_- } \\
\text { REGULATION }\end{array}$ & & & $\begin{array}{l}0.003^{\star \star} \\
(0.012)\end{array}$ & & & & $\begin{array}{l}0.003^{* * *} \\
(0.001)\end{array}$ & \\
\hline $\begin{array}{l}\text { SUPERVISORY } \\
\text { POWER }\end{array}$ & & & & $\begin{array}{l}0.003^{\star \star \star} \\
(0.001)\end{array}$ & & & & $\begin{array}{c}0.004^{\star \star \star} \\
(0.000)\end{array}$ \\
\hline $\ln (G D P)$ & $\begin{array}{l}0.023^{* * *} \\
(0.000)\end{array}$ & $\begin{array}{l}0.022^{\star * *} \\
(0.000)\end{array}$ & $\begin{array}{l}0.022^{\star \star \star} \\
(0.000)\end{array}$ & $\begin{array}{l}0.022^{\star \star \star} \\
(0.000)\end{array}$ & $\begin{array}{l}0.032^{\star \star *} \\
(0.000)\end{array}$ & $\begin{array}{l}0.031^{* * *} \\
(0.000)\end{array}$ & $\begin{array}{l}0.031^{* * *} \\
(0.000)\end{array}$ & $\begin{array}{l}0.032^{\star \star \star} \\
(0.000)\end{array}$ \\
\hline GDPG & $\begin{array}{c}-0.004 \\
(0.714)\end{array}$ & $\begin{array}{c}-0.008 \\
(0.445)\end{array}$ & $\begin{array}{c}-0.007 \\
(0.505)\end{array}$ & $\begin{array}{c}-0.004 \\
(0.699)\end{array}$ & $\begin{array}{c}-0.008 \\
(0.577)\end{array}$ & $\begin{array}{c}-0.015 \\
(0.327)\end{array}$ & $\begin{array}{c}-0.013 \\
(0.382)\end{array}$ & $\begin{array}{c}-0.009 \\
(0.560)\end{array}$ \\
\hline GDPG_CORRELATION & $\begin{array}{l}0.018^{\star *} \\
(0.035)\end{array}$ & $\begin{array}{l}0.0199^{* *} \\
(0.028)\end{array}$ & $\begin{array}{l}0.021^{\star \star} \\
(0.015)\end{array}$ & $\begin{array}{l}0.023^{\star \star \star} \\
(0.008)\end{array}$ & $\begin{array}{c}0.020 \\
(0.160)\end{array}$ & $\begin{array}{c}0.020 \\
(0.150)\end{array}$ & $\begin{array}{l}0.026^{\star \star \star} \\
(0.005)\end{array}$ & $\begin{array}{l}0.027^{\star} \\
(0.052)\end{array}$ \\
\hline $\ln (\mathrm{GDPPC})$ & $\begin{array}{l}-0.008^{\star * *} \\
(0.005)\end{array}$ & $\begin{array}{l}-0.008^{\star * *} \\
(0.010)\end{array}$ & $\begin{array}{c}-0.007^{\star \star} \\
(0.023)\end{array}$ & $\begin{array}{l}-0.008^{\star \star \star} \\
(0.007)\end{array}$ & $\begin{array}{l}-0.014^{* \star *} \\
(0.004)\end{array}$ & $\begin{array}{l}-0.013^{* * *} \\
(0.007)\end{array}$ & $\begin{array}{l}-0.011^{* \star *} \\
(0.000)\end{array}$ & $\begin{array}{c}-0.013^{\star \star \star} \\
(0.006)\end{array}$ \\
\hline BILATERAL_TRADE & $\begin{array}{l}0.010^{\star \star \star} \\
(0.008)\end{array}$ & $\begin{array}{l}0.011^{\star \star \star} \\
(0.005)\end{array}$ & $\begin{array}{l}0.008^{\star \star} \\
(0.035)\end{array}$ & $\begin{array}{l}0.010^{\star \star} \\
(0.012)\end{array}$ & $\begin{array}{c}0.011 \\
(0.120)\end{array}$ & $\begin{array}{r}0.012^{*} \\
(0.072)\end{array}$ & $\begin{array}{l}0.008^{* \star} \\
(0.014)\end{array}$ & $\begin{array}{c}0.010 \\
(0.151)\end{array}$ \\
\hline $\begin{array}{l}\text { COUNTRY } \\
\text { GOVERNANCE }\end{array}$ & $\begin{array}{l}0.028^{\star * *} \\
(0.000)\end{array}$ & $\begin{array}{l}0.025^{\star \star *} \\
(0.000)\end{array}$ & $\begin{array}{l}0.027^{\star \star \star} \\
(0.000)\end{array}$ & $\begin{array}{l}0.030^{\star \star \star} \\
(0.000)\end{array}$ & $\begin{array}{l}0.050^{* * *} \\
(0.000)\end{array}$ & $\begin{array}{l}0.046^{* \star *} \\
(0.000)\end{array}$ & $\begin{array}{l}0.049^{\star \star *} \\
(0.000)\end{array}$ & $\begin{array}{l}0.053^{\star \star \star} \\
(0.000)\end{array}$ \\
\hline CREDIT_TO_GDP & $\begin{array}{l}0.038^{* * *} \\
(0.000)\end{array}$ & $\begin{array}{l}0.037^{\star \star \star} \\
(0.000)\end{array}$ & $\begin{array}{l}0.042^{\star \star \star} \\
(0.000)\end{array}$ & $\begin{array}{l}0.039^{\star \star \star} \\
(0.000)\end{array}$ & $\begin{array}{l}0.075^{\star \star \star} \\
(0.000)\end{array}$ & $\begin{array}{l}0.074^{* * *} \\
(0.000)\end{array}$ & $\begin{array}{l}0.081^{\star * \star} \\
(0.000)\end{array}$ & $\begin{array}{l}0.077^{\star \star \star} \\
(0.000)\end{array}$ \\
\hline $\begin{array}{l}\text { BORROWER_\&_CREDITOR_ } \\
\text { RIGHTS }\end{array}$ & $\begin{array}{l}-0.005^{\star * *} \\
(0.000)\end{array}$ & $\begin{array}{l}-0.005^{* \star *} \\
(0.000)\end{array}$ & $\begin{array}{l}-0.004^{\star \star \star} \\
(0.000)\end{array}$ & $\begin{array}{l}-0.004^{* \star *} \\
(0.000)\end{array}$ & $\begin{array}{l}-0.006^{* \star *} \\
(0.002)\end{array}$ & $\begin{array}{l}-0.007^{\star * *} \\
(0.001)\end{array}$ & $\begin{array}{l}-0.006^{* * *} \\
(0.000)\end{array}$ & $\begin{array}{l}-0.006^{\star \star *} \\
(0.005)\end{array}$ \\
\hline $\begin{array}{l}\text { BANKING } \\
\text { CONCENTRATION }\end{array}$ & $\begin{array}{l}-0.053^{\star \star \star} \\
(0.002)\end{array}$ & $\begin{array}{l}-0.047^{\star \star \star} \\
(0.006)\end{array}$ & $\begin{array}{l}-0.062^{\star \star \star} \\
(0.000)\end{array}$ & $\begin{array}{l}-0.054^{\star \star \star} \\
(0.002)\end{array}$ & $\begin{array}{l}-0.119^{\star \star \star} \\
(0.001)\end{array}$ & $\begin{array}{l}-0.108^{* * *} \\
(0.002)\end{array}$ & $\begin{array}{l}-0.129^{\star \star \star} \\
(0.000)\end{array}$ & $\begin{array}{l}-0.120^{\star \star \star} \\
(0.000)\end{array}$ \\
\hline $\begin{array}{l}\text { BANKING } \\
\text { PROFITABILITY }\end{array}$ & $\begin{array}{c}-0.007 \\
(0.613)\end{array}$ & $\begin{array}{c}-0.006 \\
(0.678)\end{array}$ & $\begin{array}{c}-0.004 \\
(0.780)\end{array}$ & $\begin{array}{c}-0.011 \\
(0.422)\end{array}$ & $\begin{array}{c}0.012 \\
(0.533)\end{array}$ & $\begin{array}{l}0.015 \\
(0.464)\end{array}$ & $\begin{array}{l}0.015 \\
(0.292)\end{array}$ & $\begin{array}{l}0.006 \\
(0.762)\end{array}$ \\
\hline $\begin{array}{l}\text { OFFSHORE_FINANCIAL_ } \\
\text { CENTER }\end{array}$ & $\begin{array}{l}0.034^{* * *} \\
(0.001)\end{array}$ & $\begin{array}{l}0.034^{* \star *} \\
(0.001)\end{array}$ & $\begin{array}{l}0.025^{\star *} \\
(0.010)\end{array}$ & $\begin{array}{l}0.031^{\star \star \star} \\
(0.002)\end{array}$ & $\begin{array}{l}0.037^{* *} \\
(0.028)\end{array}$ & $\begin{array}{l}0.037^{* *} \\
(0.024)\end{array}$ & $\begin{array}{l}0.023^{* *} \\
(0.011)\end{array}$ & $\begin{aligned} 0.031^{*} \\
(0.064)\end{aligned}$ \\
\hline CONTIGUOUS & $\begin{array}{l}0.114^{\star \star *} \\
(0.007)\end{array}$ & $\begin{array}{l}0.124^{\star \star \star} \\
(0.003)\end{array}$ & $\begin{array}{l}0.120^{\star \star \star} \\
(0.005)\end{array}$ & $\begin{array}{l}0.120^{\star \star \star} \\
(0.005)\end{array}$ & $\begin{array}{l}0.107 \\
(0.195)\end{array}$ & $\begin{array}{c}0.122 \\
(0.136)\end{array}$ & $\begin{array}{l}0.120^{\star \star \star} \\
(0.000)\end{array}$ & $\begin{array}{c}0.116 \\
(0.156)\end{array}$ \\
\hline COMMON_LANGUAGE & $\begin{array}{l}0.053^{* * *} \\
(0.000)\end{array}$ & $\begin{array}{l}0.052^{* \star *} \\
(0.000)\end{array}$ & 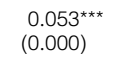 & $\begin{array}{l}0.049^{\star \star *} \\
(0.000)\end{array}$ & $\begin{array}{l}0.113^{\text {***}} \\
(0.000)\end{array}$ & $\begin{array}{l}0.113^{* * *} \\
(0.000)\end{array}$ & $\begin{array}{l}0.111^{\text {***}} \\
(0.000)\end{array}$ & $\begin{array}{l}0.108^{\star \star \star} \\
(0.000)\end{array}$ \\
\hline In(DISTANCE) & $\begin{array}{c}0.004 \\
(0.592)\end{array}$ & $\begin{array}{c}0.005 \\
(0.490)\end{array}$ & $\begin{array}{c}0.001 \\
(0.862)\end{array}$ & $\begin{array}{c}0.003 \\
(0.717)\end{array}$ & $\begin{array}{c}-0.009 \\
(0.543)\end{array}$ & $\begin{array}{c}-0.007 \\
(0.643)\end{array}$ & $\begin{array}{c}-0.013^{\star \star} \\
(0.011)\end{array}$ & $\begin{array}{c}-0.011 \\
(0.462)\end{array}$ \\
\hline $\begin{array}{l}\text { No. of obs. } \\
\text { Adj. } R^{2}\end{array}$ & $\begin{array}{c}43,739 \\
0.30\end{array}$ & $\begin{array}{c}43,739 \\
0.30\end{array}$ & $\begin{array}{c}43,739 \\
0.30\end{array}$ & $\begin{array}{c}43,739 \\
0.30\end{array}$ & $\begin{array}{c}43,739 \\
0.29\end{array}$ & $\begin{array}{c}43,739 \\
0.29\end{array}$ & $\begin{array}{c}43,739 \\
0.29\end{array}$ & $\begin{array}{c}43,739 \\
0.29\end{array}$ \\
\hline
\end{tabular}

increases of approximately $2.2 \%, 0.5 \%$, and $1.0 \%$ in the number of subsidiaries on average. All coefficients are significant at the $1 \%$ level.

The estimated coefficients on the control variables are largely consistent with findings in the extant literature. We find that country presence is positively 
associated with measures of economy size, capital market development, and institutional quality. We also find that BHCs are more likely to operate foreign subsidiaries in offshore financial centers and in countries with lower levels of banking concentration. Finally, U.S. BHCs are more likely to establish foreign subsidiaries in countries that are contiguous to the United States (i.e., Mexico and Canada) and countries whose official language is English.

\section{B. Endogeneity and Reverse Causality}

One may naturally be concerned about the possibility that endogeneity or reverse causality is driving our empirical relationships. For example, expected improvement in country-specific economic conditions, which can be accompanied by a relaxation of regulation and supervision standards, could provide incentives for U.S. banking organizations to increase their exposure to the improving economies and, consequently, bolster their local presence. Alternatively, political channels may allow U.S. BHCs to shape foreign regulatory environments. To precisely identify the effects of the regulatory environment in our setting, we need an exogenous shock to the stringency of regulation and supervision at the country level, independent of other national factors. Identifying such a shock is unlikely, and even if it could be found, it is improbable that the effects and institutional details would be comparable across countries. For these reasons, we follow the prior literature and choose a general approach to identify the effect of country regulatory stringency using IVs.

We follow Demirgüç-Kunt and Detragiache (2002) and Houston et al. (2012), who interpret trends in banking policies as a potential source of exogenous variation in a specific country's banking regulations manifested through a "regulation contagion" channel. We further refine this idea with findings from Abiad and Mody (2005), Persson and Tabellini (2009), Buera, Monge-Naranjo, and Primiceri (2011), and Masciandaro and Romelli (2018), who emphasize the influence of neighboring countries over a country's institutional environment through spillover effects. For each country, we use the median of neighboring countries' REGULATION_\&_SUPERVISION as an instrumental variable for the country's regulatory environment. To mitigate concerns of unobserved effects related to the expectations of future economic outcomes (e.g., expected regional economic growth), our instrument uses (lagged) regulatory stringency values from preceding data surveys. The validity of our instrumental variable, which we call NBR_REG_\&_SUP, depends on the exclusion restriction that, conditional on the included controls, values of neighboring countries' lagged regulation and supervision stringency do not affect U.S. BHCs' operations of foreign subsidiaries in a particular country other than through the effect on that country's own regulation and supervision environment. Table 4 presents the results.

Column 1 of Panel A in Table 4 reports the first-stage estimation results. The estimated coefficient of NBR_REG_\&_SUP is positive and highly significant. In addition, the adjusted $R^{2}$ and F-statistic are above the threshold of 10 prescribed by Stock and Yogo (2005), which suggests that our IV estimations do not suffer from weak-instrument problems. Columns 1 and 2 of Panel B show that the estimated coefficients on REGULATION_\&_SUPERVISION retain their signs and 
TABLE 4

Instrumental Variable Specifications

Table 4 reports coefficient estimates from instrumental variable (IV) panel regressions of U.S. bank holding company $(\mathrm{BHC})$ subsidiary locations on foreign banking regulation and supervision stringency and control variables. The sample is a panel of BHC-year-subsidiary country observations during the period 1995-2013 of 135 U.S. BHCs. PRESSUB is an indicator variable that equals 1 if a $\mathrm{BHC}$ reports having foreign subsidiaries in a given country during a year, and 0 otherwise. In(NSUB) is the natural logarithm of 1 plus the total number of subsidiaries a BHC has in a given country during a year. REGULATION_\&_SUPERVISION measures the stringency of a country's banking regulation and supervision. It is defined as the first principal component of 3 regulation and supervision indices: ACTIVITY_RESTRICTIONS, CAPITAL_REGULATION, and SUPERVISORY_POWER. NBR_REG_\&_SUP is the median of neighboring countries' REGULATION_\&_SUPERVISION using data values from the preceding survey. GLBL_REG_\&_SUP is the median of REGULATION_\&_SUPERVISION across all countries in the sample using data values from the preceding survey. NBR_ADJ_REG_\&_SUP is the difference between a country's REGULATION_\&_SUPERVISION, using data values from the preceding survey, and NBR_REG_\&_SUP. SYSTEMIC_CRISES is the number of systemic crises a country had during the 1970s and 1980s. GOVT_OWNERSHIP is the share of assets of the top 10 banks in a country owned by the government of that country in 1970. INDEPENDENT_PCT is the percentage of years since 1776 a country has been independent. Panel A presents first-stage results, and Panel B presents second-stage results. In Panel B, we use NBR_REG_\&_SUP in columns 1 and 2; GLBL_REG_\&_SUP in columns 3 and 4; NBR_ADJ_REG_\&_SUP in columns 5 and 6; and SYSTEMIC_CRISES, GOVT_OWNERSHIP, and INDEPENDENT_PCT in columns 7 and 8 , respectively, as IVs for the stringency of regulation and supervision. Detailed definitions of all variables are presented in the Appendix. Control variables are the same as used in Table 3 , but their coefficient estimates are omitted for brevity. We include BHC $x$ year fixed effects in all specifications except for columns 3 and 4 , where we use BHC fixed effects. We use robust standard errors clustered at the BHC $\times$ country level in all specifications. $p$-values are reported in parentheses. ${ }^{*},{ }^{* *}$, and *** indicate significance at the $10 \%, 5 \%$, and $1 \%$ levels, respectively.

Panel A. First-Stage IV Estimations

REGULATION_\&_SUPERVISION

$\frac{\text { Variable }}{\text { NBR_REG_\&_SUP }}$
GLBL_REG_\&_SUP
NBR_ADJ_REG_\&_S
SYSTEMIC_CRISES
GOVT_OWNERSHIP
INDEPENDENT_PCT

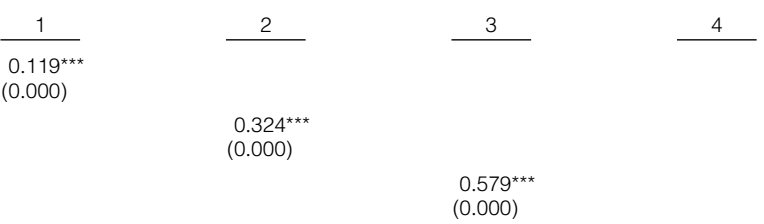

\section{Controls}

No. of obs.

Adj. $R^{2}$

Y.605

0.20

$\begin{array}{cc}\text { Yes } & \text { Yes } \\ 605 & 34,092 \\ .20 & 0.18\end{array}$

Yes

0.18

$-0.078^{\star \star \star}$
$(0.000)$

$-0.559^{\star \star \star}$

(0.000)

$-0.002^{\star \star \star}$

(0.000)

Yes

24,461

0.39

Panel B. Second-Stage IV Estimations

IVs: SYSTEMIC_CRISES, GOVT_OWNERSHIP,

IV: NBR_REG_\&_SUP IV: GLBL_REG_\&_SUP IV: NBR_ADJ_REG_\&_SUP and INDEPENDENT_PCT

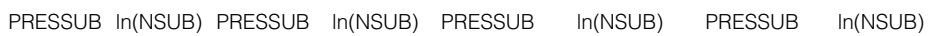

\begin{tabular}{|c|c|c|c|c|c|c|c|c|}
\hline Variable & 1 & 2 & 3 & 4 & 5 & 6 & 7 & 8 \\
\hline $\begin{array}{l}\text { REGULATION_\& } \\
\text { SUPERVISION }\end{array}$ & $\begin{array}{l}0.039^{\star \star \star} \\
(0.002)\end{array}$ & $\begin{array}{l}0.081^{\star \star \star} \\
(0.001)\end{array}$ & $\begin{array}{l}0.046^{\star \star *} \\
(0.001)\end{array}$ & $\begin{array}{l}0.083^{\star \star \star} \\
(0.000)\end{array}$ & $\begin{array}{l}0.004^{* \star *} \\
(0.006)\end{array}$ & $\begin{array}{l}0.007^{\star * \star} \\
(0.009)\end{array}$ & $\begin{array}{l}0.026^{* \star \star} \\
(0.004)\end{array}$ & $\begin{array}{l}0.129^{\star \star *} \\
(0.000)\end{array}$ \\
\hline Controls & Yes & Yes & Yes & Yes & Yes & Yes & Yes & Yes \\
\hline No. of obs. & 23,605 & 23,605 & 34,092 & 34,092 & 23,605 & 23,605 & 24,461 & 24,461 \\
\hline $\begin{array}{l}\text { Adj. } R^{2} \\
\text { Hansen } J \text {-statistic } \\
\text { ( } p \text {-value) }\end{array}$ & 0.33 & 0.32 & 0.30 & 0.28 & 0.33 & 0.31 & $\begin{array}{c}0.37 \\
(0.143)\end{array}$ & $\begin{array}{c}0.38 \\
(0.282)\end{array}$ \\
\hline
\end{tabular}

are significant at the $1 \%$ level. The results confirm that U.S. BHCs are more likely to operate subsidiaries in countries with weaker regulation and supervision.

Although unlikely, our instrument is susceptible to the concern that lagged neighboring countries' regulatory stringency could directly affect U.S. BHCs' operations of foreign subsidiaries in a country through some non-regulation-related 
channel, whose effects are not captured by the control variables. We mitigate such concerns with instruments using variation in regulation and supervision at the global and country-idiosyncratic (as opposed to neighboring-country) levels as sources of potentially exogenous variation. First, we use the median regulation and supervision stringency across all countries in our sample using values from preceding surveys (GLBL_REG_\&_SUP). Second, we use the difference between a given country's regulation and supervision stringency and the median of neighboring countries' regulation and supervision stringency, in both cases using data values from the preceding surveys, as another instrument (NBR_ADJ_REG_\&_SUP). Columns 3-6 in Panel B show the robustness of our results.

Finally, we show that our results are robust to a set of instruments from the prior literature: the percentage of years since 1776 a country has been independent (Beck, Demirgüç-Kunt, and Levine (2006), Karolyi and Taboada (2015)), the government ownership of banks in 1970 (La Porta, Lopez-de-Silanes, Shleifer, and Vishny (2002), Karolyi and Taboada (2015)), and the number of systemic crises in the 1970s and 1980s (Laeven and Valencia (2013), Karolyi and Taboada (2015)). Countries that have been independent for longer periods of time may have had more opportunities to develop banking policies that are conducive to economic growth. Likewise, countries may change banking regulation and supervision policies after systemic crises, and government ownership in the banking sector may also affect the government's ability to implement and change banking policies. Notably, these instruments are particularly useful against reverse-causality concerns because they represent country measurements from decades ago and are unlikely to be correlated with contemporaneous effects of U.S. BHC presence on the regulatory environments of host countries. Columns 7 and 8 in Panel B of Table 4 again confirm our previously documented results. ${ }^{15}$

\section{Risk-Management Quality}

Ellul and Yerramilli (2013) find that the strength of risk management and internal controls can curtail BHC risk exposures. Consequently, we examine whether banking organizations' propensity to exploit cross-country differences in regulation and supervision is related to their ability to identify, measure, monitor, and control risk.

To study this issue, we use a risk-management rating from the Federal Reserve's RFI/C(D) and BOPEC rating systems. The rating comprises 4 dimensions: i) board and senior management oversight; ii) policies, procedures, and limits; iii) risk monitoring; and iv) internal controls. It ranges from 1 to 5 and is decreasing in the quality of risk management. According to the Bank Holding Company Supervision Manual, a BHC with a rating of 3 or higher exhibits fair to severe

\footnotetext{
${ }^{15}$ Although our IV analyses mitigate concerns that the results in Table 3 are driven by countryspecific factors not related to regulatory stringency, we further confirm this with an analysis of expansions and contractions of subsidiary counts, where we partial out country-specific factors that are invariant over time by using difference regressions. See the Supplementary Material for more details.
} 
risk-management weaknesses. ${ }^{16}$ Consistent with this definition, we create an indicator variable for weak risk management, WRM, equal to 1 if a $\mathrm{BHC}$ has a rating greater than or equal to 3 , and 0 otherwise. ${ }^{17}$

The advantage of using a supervisory risk-management rating is that it should encompass both public and private information and hence provide a comprehensive assessment of an institution's risk-management processes. Nevertheless, as an additional test, we also examine the relationship between BHC risk management, subsidiary locations, and foreign regulatory environments using the risk-management index (RMI) developed and generously provided to us by Ellul and Yerramilli (2013). The RMI is a continuous measure of the organizational strength and independence of the risk-management function at a given BHC during a given year based on public data. Specifically, the RMI is constructed as the first principal component of 7 measures of BHC risk-management quality, including variables that capture whether a $\mathrm{BHC}$ has a designated risk officer to manage enterprise-wide risk and variables that capture how well quantitative and qualitative information on risk is shared between the top management and the business segments of a BHC. For comparability to WRM, we transform the original RMI to be decreasing in the quality of BHCs' risk management.

We estimate a model similar to equation (1) but include interactions between WRM (RMI) and REGULATION_\&_SUPERVISION. Due to the inclusion of BHC-year fixed effects, we are unable to identify the coefficients on WRM (RMI) individually. Table 5 presents the results.

The coefficient estimates on WRM $\times$ REGULATION_\&_SUPERVISION are negative and significant at the $1 \%$ level. BHCs operating subsidiaries in countries with weak regulatory environments tend to have stronger risk-management functions. Decreasing the stringency of the regulatory environment by 1 standard deviation and contemporaneously switching the quality of BHC risk management from "strong" to "weak" reduces the likelihood of subsidiary presence (the number of BHC subsidiaries) in a given country by 2.8 percentage points $(4.8 \%)$. This empirical relation may reflect BHC choices or supervisory limitations on cross-border expansions. Either way, this result mitigates some of the increased risk-taking concerns associated with cross-border regulatory arbitrage. The link between subsidiary locations, regulation and supervision stringency, and BHC risk-management quality is also robust when using RMI instead of WRM. The coefficient estimates of RMI $\times$ REGULATION_\&_SUPERVISION are consistently negative and significant at least at the $10 \%$ level.

\footnotetext{
${ }^{16}$ More information on the RFI/C(D) and BOPEC rating systems can be found at https://www .federalregister.gov/documents/2004/12/06/04-26723/bank-holding-company-rating-system. The Bank Holding Company Supervision Manual can be found at https://www.federalreserve.gov/ publications/files/bhc.pdf.

${ }^{17} \mathrm{We}$ use an indicator variable as opposed to the original risk management index because we face thin data at each extreme of the index's distribution. In addition, the index is based on an ordinal scale, and thus individual values have no particular meaning beyond establishing a ranking among institutions.
} 
TABLE 5

Subsidiary Locations and BHC Risk-Management Quality

Table 5 reports coefficient estimates from panel regressions of U.S. bank holding company (BHC) subsidiary locations on foreign banking regulation and supervision stringency, interactions with BHC risk-management quality, and control variables. The sample is a panel of BHC-year-subsidiary country observations during the period 1995-2013 of 135 U.S. BHCs. PRESSUB is an indicator variable that equals 1 if a $\mathrm{BHC}$ reports having foreign subsidiaries in a given country during a year, and 0 otherwise. In(NSUB) is the natural logarithm of 1 plus the total number of subsidiaries a BHC has in a given country during a year. REGULATION_\&_SUPERVISION measures the stringency of a country's banking regulation and supervision. It is defined as the first principal component of ACTIVITY_RESTRICTIONS, CAPITAL_REGULATION, and SUPERVISORY_POWER. ACTIVITY_RESTRICTIONS measures the stringency of a country's regulation regarding banks' involvement in securities, insurance, and real estate activities. CAPITAL_REGULATION measures the degree to which supervisory authorities in a country oversee capital at risk and the initial source of funds used to capitalize a bank. SUPERVISORY_POWER measures the extent to which supervisory authorities in a country can intervene to prevent and correct problems at financial institutions. WRM is an indicator variable for weak risk-management practices at a given $\mathrm{BHC}$ during a year. WRM equals 1 if a BHC has a Federal Reserve System risk-management rating (ranging from 1 to 5 ) that is greater than or equal to 3 , and 0 otherwise. RMI measures the organizational strength and independence of the risk-management function at a given BHC during a year (Ellul and Yerramilli (2013)). Detailed definitions of all variables are presented in the Appendix. Control variables are the same as used in Table 3, but their coefficient estimates are omitted for brevity. We include BHC $\times$ year fixed effects and use robust standard errors clustered at the $\mathrm{BHC} \times$ country level in all specifications. $p$-values are reported in parentheses. * ${ }^{* *}$, and ${ }^{* * *}$ indicate significance at the $10 \%, 5 \%$, and $1 \%$ levels, respectively.

\begin{tabular}{|c|c|c|c|c|}
\hline \multirow[b]{2}{*}{ Variable } & \multicolumn{2}{|c|}{ PRESSUB } & \multicolumn{2}{|c|}{$\ln ($ NSUB $)$} \\
\hline & 1 & 2 & 3 & 4 \\
\hline REGULATION_\&_SUPERVISION & $\begin{array}{l}0.013^{\star \star \star} \\
(0.000)\end{array}$ & $\begin{array}{l}0.019^{\star \star \star} \\
(0.000)\end{array}$ & $\begin{array}{l}0.021^{\star \star \star} \\
(0.000)\end{array}$ & $\begin{array}{l}0.042^{\star \star \star} \\
(0.000)\end{array}$ \\
\hline WRM $\times$ REGULATION_\&_SUPERVISION & $\begin{array}{c}-0.025^{\star \star \star} \\
(0.000)\end{array}$ & & $\begin{array}{l}-0.042^{\star \star \star} \\
(0.000)\end{array}$ & \\
\hline RMI $\times$ REGULATION_\&_SUPERVISION & & $\begin{array}{r}-0.008^{\star} \\
(0.081)\end{array}$ & & $\begin{array}{c}-0.029^{\star \star \star} \\
(0.000)\end{array}$ \\
\hline Controls & Yes & Yes & Yes & Yes \\
\hline $\begin{array}{l}\text { No. of obs. } \\
\text { Adj. } R^{2}\end{array}$ & $\begin{array}{c}37,847 \\
0.30\end{array}$ & $\begin{array}{c}23,345 \\
0.34\end{array}$ & $\begin{array}{c}37,847 \\
0.29\end{array}$ & $\begin{array}{c}23,345 \\
0.33\end{array}$ \\
\hline
\end{tabular}

\section{BHC Risk}

\section{A. BHC-Level Data}

Given that many of the globally important financial firms are U.S. institutions, understanding the risks associated with BHCs' cross-border activities is imperative. As discussed in Section II, regulatory arbitrage can be conducive to increased risk taking. To test our hypothesis, we focus on a subset of our initial data, conditioning only on observations that indicate BHC presence. We expand the panel of BHC-year-subsidiary country observations to a panel of BHC-quarter-subsidiary countries to match the quarterly frequency of BHC financial data. Because we face multiple instances per BHC-quarter (one observation for every country of exposure), our baseline results use subsidiary count weights within a BHC-quarter to "collapse" BHC-quarter-subsidiary country observations of country-level variables to the BHC-quarter level. We do this for all country-level variables, including our main regulatory stringency index REGULATION_\&_SUPERVISION. ${ }^{18}$

\footnotetext{
${ }^{18}$ In unreported robustness checks, we confirm our results using 3 alternative weighting schemes: i) weighting each country exposure within a BHC-quarter equally, ii) weighting each country exposure within a BHC-quarter proportionately to a BHC's local claims in countries, and iii) weighting each country exposure within a BHC-quarter proportionately to the size of a country's GDP in a given quarter.
} 
To measure risk, we use VAR and $\triangle$ COVAR from Adrian and Brunnermeier (2016). VAR captures BHC stand-alone risk and is defined as a BHC's unconditional maximum market equity return loss at the $95 \%$ confidence level on a quarterly basis. $\triangle$ COVAR captures a BHC's contribution to systemic risk and is defined as the difference between the conditional value at risk (COVAR) of the financial system conditional on a particular institution being in distress (95\% quantile of quarterly equity return losses) and the COVAR conditional on the median state of that institution. ${ }^{19}$

We also control for other factors that can affect BHC risk outcomes in our empirical analysis. First, we include the full set of host-country-level controls used in Section IV. Second, we control for U.S. financial market volatility. Third, we control for BHC-level characteristics, including size, leverage, market-to-book ratio, the ratio of noninterest to interest income, the ratio of deposits to total assets, and foreign assets share. To avoid any potential bias from outliers, we winsorize all continuous BHC-level variables at the 1 st and 99 th percentiles. The availability of risk and other BHC-level data reduces the number of BHCs in the cross section from 135 to 64 .

Table 6 presents summary statistics for the variables used in our risk analysis in Panel A and pairwise correlations between REGULATION_\&_SUPERVISION and the BHC risk measures in Panel B.

Panel A of Table 6 shows that the mean and standard deviation of VAR are $5.6 \%$ and $2.2 \%$, respectively, and the mean and standard deviation of $\triangle$ COVAR are $1.6 \%$ and $0.7 \%$, respectively. These summary statistics combined with the ranges of the 2 variables $(13.5 \%$ for VAR and $3.5 \%$ for $\triangle$ COVAR) suggest substantial variation of BHC risk in our sample. Panel B shows that both measures of risk are significantly positively correlated with REGULATION_\&_SUPERVISION. This is consistent with the interpretation that BHC risk and contribution to systemic risk increase when the regulatory environments for BHCs' foreign subsidiaries are weaker.

\section{B. BHC Risk and Regulatory Stringency}

We next explore the relation between regulation and supervision of subsidiary locations and $\mathrm{BHC}$ risk in a multivariate panel-regression framework. We estimate the following model via OLS:

$$
Z_{i, t}=\alpha_{i}+\beta \text { REGULATION_\&_SUPERVISION } I_{i, t-1}+\delta X_{i, t-1}+\epsilon_{i, t},
$$

where $i$ indexes BHCs and $t$ indexes quarters, $Z_{i, t}$ is $\operatorname{VAR}_{i, t}$ or $\triangle \operatorname{COVAR}_{i, t}$, and REGULATION_\&_SUPERVISION ${ }_{i, t-1}$ measures the average regulatory stringency of subsidiary locations. $X_{i, t-1}$ is a vector of control variables capturing the host-country environment, U.S. financial market conditions, and BHC-level

\footnotetext{
${ }^{19}$ Our results are qualitatively similar if we use the $99 \%$ instead of the $95 \%$ quantile for VAR and $\triangle$ COVAR. In addition, our results are robust to using alternative risk measures. For example, we confirmed our results using the natural logarithm of daily $\mathrm{BHC}$ return variance estimated over a calendar quarter as an alternative measure of BHC stand-alone risk and the marginal expected shortfall (MES) defined by Acharya, Pedersen, Philippon, and Richardson (2016) as an alternative measure of systemic risk.
} 
TABLE 6

\section{Summary Statistics and Variable Correlations}

Table 6 presents summary statistics (Panel A) and pairwise correlations (Panel B) of the main variables in our analysis. The sample is a panel of 1,502 bank holding company (BHC)-quarter observations during the period 1995:Q1-2013:Q4 of 64 U.S. BHCs. Subsidiary count weights within a BHC-quarter are used to "collapse" BHC-quarter-subsidiary country observations to the BHC-quarter level. Detailed definitions of all variables are presented in the Appendix. $p$-values are reported in parentheses. ${ }^{*},{ }^{* *}$, and ${ }^{* * *}$ indicate significance at the $10 \%, 5 \%$, and $1 \%$ levels, respectively.

Panel A. Summary Statistics

\begin{tabular}{|c|c|c|c|c|c|}
\hline Country & Mean & Std. Dev. & Minimum & Maximum & No. of Obs. \\
\hline VAR & 5.644 & 2.232 & 2.560 & 16.013 & 1,502 \\
\hline$\triangle$ COVAR & 1.577 & 0.650 & 0.365 & 3.854 & 1,502 \\
\hline REGULATION_\&_SUPERVISION & 4.243 & 0.874 & 1.572 & 6.027 & 1,502 \\
\hline ACTIVITY_RESTRICTIONS & 6.931 & 1.233 & 2.200 & 9 & 1,502 \\
\hline CAPITAL_REGULATION & 3.793 & 1.122 & 1 & 6.667 & 1,502 \\
\hline SUPERVISORY_POWER & 6.304 & 1.783 & 2.800 & 10 & 1,502 \\
\hline $\ln (\mathrm{GDP})$ & 27.227 & 0.984 & 23.623 & 28.645 & 1,502 \\
\hline GDPG & 0.038 & 0.071 & -0.332 & 0.214 & 1,502 \\
\hline GDPG_CORRELATION & 0.463 & 0.200 & 0.003 & 1.746 & 1,502 \\
\hline $\ln (G D P P C)$ & 10.270 & 0.540 & 6.743 & 11.477 & 1,502 \\
\hline BILATERAL_TRADE & 0.328 & 0.266 & 0.014 & 1.043 & 1,502 \\
\hline COUNTRY_GOVERNANCE & 1.385 & 0.313 & -0.366 & 1.746 & 1,502 \\
\hline CREDIT_TO_GDP & 1.243 & 0.339 & 0 & 10 & 1,502 \\
\hline BORROWER_\&_CREDITOR_RIGHTS & 7.569 & 1.564 & 3 & 1.978 & 1,502 \\
\hline BANKING_CONCENTRATION & 0.617 & 0.161 & 0.120 & 0.889 & 1,502 \\
\hline BANKING_SECTOR_PROFITABILITY & 0.103 & 0.074 & -0.266 & 0.364 & 1,502 \\
\hline OFFSHORE_FINANCIAL_CENTER & 0.175 & 0.303 & 0 & 1 & 1,502 \\
\hline CONTIGUOÜS & 0.290 & 0.353 & 0 & 1 & 1,502 \\
\hline COMMON_LANGUAGE & 0.734 & 0.291 & 0 & 1 & 1,502 \\
\hline In(DISTANC̄E) & 8.146 & 0.946 & 6.307 & 9.681 & 1,502 \\
\hline MARKET_VOLATILITY & 1.119 & 0.565 & 0.498 & 4.159 & 1,502 \\
\hline $\ln (A S S E T \bar{S})$ & 18.307 & 1.616 & 12.558 & 21.594 & 1,502 \\
\hline LEVERAGE & 11.544 & 3.704 & 3.468 & 44.408 & 1,502 \\
\hline FOREIGN_ASSETS_PCT & 0.073 & 0.089 & 0 & 0.349 & 1,502 \\
\hline INCOME_MIX & 1.452 & 3.289 & -0.006 & 17.676 & 1,502 \\
\hline MARKET_TO_BOOK & 1.984 & 1.076 & 0.314 & 5.258 & 1,502 \\
\hline DEPOSITS_PCT & 0.576 & 0.197 & 0.015 & 0.891 & 1,502 \\
\hline \multicolumn{6}{|l|}{ Panel B. Pairwise Correlations } \\
\hline Variable & \multicolumn{2}{|c|}{$\begin{array}{l}\text { REGULATION_\& } \\
\text { SUPERVISION }\end{array}$} & \multicolumn{2}{|c|}{ VAR } & $\triangle$ COVAR \\
\hline $\begin{array}{l}\text { REGULATION_\& } \\
\text { SUPERVISION }\end{array}$ & \multicolumn{2}{|l|}{1.000} & & & \\
\hline VAR & \multicolumn{2}{|c|}{$\begin{array}{l}0.080^{\star \star \star} \\
(0.000)\end{array}$} & \multicolumn{2}{|c|}{1.000} & \\
\hline$\triangle$ COVAR & \multicolumn{2}{|c|}{$\begin{array}{l}0.099^{\star \star \star} \\
(0.000)\end{array}$} & \multicolumn{2}{|c|}{$\begin{array}{l}0.656^{\star \star \star} \\
(0.000)\end{array}$} & 1.000 \\
\hline
\end{tabular}

characteristics. Finally, $\alpha_{i}$ denotes BHC fixed effects. ${ }^{20}$ Error terms are clustered at the BHC level. Panel A of Table 7 presents the results.

The results in column 1 of Table 7 indicate that subsidiary operations in jurisdictions with weaker regulation and supervision are associated with an increase in BHC stand-alone risk. Furthermore, the results in column 5 show that subsidiary operations in these countries are associated with increases in BHCs' contribution to U.S. systemic risk. On average, a 1-standard-deviation increase in REGULATION_\&_SUPERVISION is associated with an $11.8 \%$ increase in VAR

\footnotetext{
${ }^{20}$ Because our baseline regression analysis focuses on the within-BHC variation of risk and how it relates to the regulatory stringency of the host countries where BHCs operate subsidiaries, we do not use time period fixed effects. However, in unreported tests, we confirm the robustness of our results to including different time period fixed effects (e.g., economic cycle fixed effects and regulatory data survey period fixed effects).
} 
TABLE 7

Risk and Foreign Regulation and Supervision Stringency

Table 7 reports coefficient estimates from panel regressions of U.S. bank holding company (BHC) risk on foreign banking regulation and supervision stringency and control variables. The sample is a panel of 1,502 BHC-quarter observations during the period 1995:Q1-2013:Q4 of 64 U.S. BHCs, where subsidiary count weights within a BHC-quarter were used to "collapse" BHC-quarter-subsidiary country observations to the BHC-quarter level. VAR is a BHC's unconditional maximum market equity loss at the $95 \%$ confidence level on a quarterly basis. $\triangle$ COVAR measures a BHC's contribution to systemic risk and is defined as the difference between the conditional value at risk (COVAR) of the financial system conditional on an institution being in distress (95\% quantile of quarterly equity return losses) and the COVAR conditional on the median state of the institution. REGULATION_\&_SUPERVISION, ACTIVITY_RESTRICTIONS, CAPITAL_REGULATION, and SUPERVISORY_POWER measure the stringency of a country's banking regulation and supervision. REGULATION_\&_SUPERVISION is defined as the first principal component of ACTIVITY_RESTRICTIONS, CAPITAL_REGULATION, and SUPERVISORY_POWER. ACTIVITY_RESTRICTIONS measures the stringency of a country's regulation regarding banks' involvement in securities, insurance, and real estate activities. CAPITAL_REGULATION measures the degree to which supervisory authorities in a country oversee capital at risk and the initial source of funds used to capitalize a bank. SUPERVISORY_POWER measures the extent to which supervisory authorities in a country can intervene to prevent and correct problems at financial institutions. Panel A presents results for overall regulation and supervision stringency. Panel B decomposes regulation and supervision stringency measures into countries that are less and more stringent than the United States. Detailed definitions of all variables are presented in the Appendix. In Panel B, control variables are the same as used in Panel A, but their coefficient estimates are omitted for brevity. We include BHC fixed effects and use robust standard errors clustered at the BHC level in all specifications. $p$-values are reported in parentheses. ${ }^{*},{ }^{* *}$, and ${ }^{* * *}$ indicate significance at the $10 \%, 5 \%$, and $1 \%$ levels, respectively.

Panel A. BHC Risk and Host-Country Regulation and Supervision

\begin{tabular}{|c|c|c|c|c|c|c|c|c|}
\hline \multirow[b]{2}{*}{ Variable } & \multicolumn{4}{|c|}{ VAR } & \multicolumn{4}{|c|}{$\triangle$ COVAR } \\
\hline & 1 & 2 & 3 & 4 & 5 & 6 & 7 & 8 \\
\hline $\begin{array}{l}\text { REGULATION_\& } \\
\text { SUPERVISION }\end{array}$ & $\begin{array}{l}0.764^{* \star \star} \\
(0.000)\end{array}$ & & & & $\begin{array}{l}0.177^{\star \star \star} \\
(0.000)\end{array}$ & & & \\
\hline ACTIVITY_RESTRICTIONS & & $\begin{array}{c}0.086 \\
(0.588)\end{array}$ & & & & $\begin{array}{c}0.020 \\
(0.553)\end{array}$ & & \\
\hline CAPITAL_REGULATION & & & $\begin{array}{l}0.549^{\star \star \star} \\
(0.000)\end{array}$ & & & & $\begin{array}{l}0.130^{\star \star \star} \\
(0.000)\end{array}$ & \\
\hline SUPERVISORY_POWER & & & & $\begin{array}{l}0.301^{\star * *} \\
(0.000)\end{array}$ & & & & $\begin{array}{l}0.070^{\star \star \star} \\
(0.000)\end{array}$ \\
\hline $\ln (G D P)$ & $\begin{array}{l}-0.940^{* *} \\
(0.014)\end{array}$ & $\begin{array}{r}-0.327 \\
(0.423)\end{array}$ & $\begin{array}{c}-0.370 \\
(0.278)\end{array}$ & $\begin{array}{c}-0.719^{\star \star} \\
(0.037)\end{array}$ & $\begin{array}{c}-0.236^{\star \star \star} \\
(0.004)\end{array}$ & $\begin{array}{c}-0.093 \\
(0.276)\end{array}$ & $\begin{array}{c}-0.105 \\
(0.150)\end{array}$ & $\begin{array}{c}-0.185^{\star \star} \\
(0.015)\end{array}$ \\
\hline GDPG & $\begin{array}{l}1.925^{* *} \\
(0.047)\end{array}$ & $\begin{array}{c}1.277 \\
(0.210)\end{array}$ & $\begin{array}{c}1.095 \\
(0.239)\end{array}$ & $\begin{array}{l}2.114^{* *} \\
(0.030)\end{array}$ & $\begin{array}{r}0.449^{*} \\
(0.077)\end{array}$ & $\begin{array}{c}0.298 \\
(0.251)\end{array}$ & $\begin{array}{c}0.255 \\
(0.283)\end{array}$ & $\begin{array}{c}0.493^{*} \\
(0.060)\end{array}$ \\
\hline GDPG_CORRELATION & $\begin{array}{c}-0.838^{* * *} \\
(0.007)\end{array}$ & $\begin{array}{c}-0.940^{\star \star *} \\
(0.001)\end{array}$ & $\begin{array}{c}-0.300 \\
(0.425)\end{array}$ & $\begin{array}{c}-0.805^{\text {*** }} \\
(0.006)\end{array}$ & $\begin{array}{r}-0.117^{*} \\
(0.092)\end{array}$ & $\begin{array}{c}-0.140^{* *} \\
(0.036)\end{array}$ & $\begin{array}{c}0.010 \\
(0.896)\end{array}$ & $\begin{array}{r}-0.110^{*} \\
(0.091)\end{array}$ \\
\hline $\ln (G D P P C)$ & $\begin{array}{l}1.416^{* \star *} \\
(0.000)\end{array}$ & $\begin{array}{l}1.744^{\star \star \star} \\
(0.000)\end{array}$ & $\begin{array}{l}1.800^{\star \star \star} \\
(0.000)\end{array}$ & $\begin{array}{l}1.225^{\star \star \star} \\
(0.000)\end{array}$ & $\begin{array}{l}0.264^{\star \star \star} \\
(0.000)\end{array}$ & $\begin{array}{l}0.340^{\star \star \star} \\
(0.000)\end{array}$ & $\begin{array}{l}0.353^{\star \star \star} \\
(0.000)\end{array}$ & $\begin{array}{l}0.219^{\star \star \star} \\
(0.001)\end{array}$ \\
\hline BILATERAL_TRADE & $\begin{array}{c}-5.673^{* * *} \\
(0.008)\end{array}$ & $\begin{array}{c}-6.234^{\star \star} \\
(0.010)\end{array}$ & $\begin{array}{c}-7.331^{\star \star \star} \\
(0.001)\end{array}$ & $\begin{array}{c}-4.610^{\star *} \\
(0.031)\end{array}$ & $\begin{array}{c}-1.100^{* *} \\
(0.014)\end{array}$ & $\begin{array}{c}-1.229^{* *} \\
(0.017)\end{array}$ & $\begin{array}{c}-1.490^{\star \star \star} \\
(0.002)\end{array}$ & $\begin{array}{r}-0.853^{*} \\
(0.061)\end{array}$ \\
\hline COUNTRY_GOVERNANCE & $\begin{array}{c}-1.644^{\star \star \star} \\
(0.005)\end{array}$ & $\begin{array}{c}-2.010^{\star \star \star} \\
(0.002)\end{array}$ & $\begin{array}{c}-1.831^{\star \star \star} \\
(0.003)\end{array}$ & $\begin{array}{c}-1.194^{\star \star} \\
(0.038)\end{array}$ & $\begin{array}{c}-0.309^{* *} \\
(0.042)\end{array}$ & $\begin{array}{c}-0.393^{\star *} \\
(0.015)\end{array}$ & $\begin{array}{c}-0.352^{\star \star} \\
(0.023)\end{array}$ & $\begin{array}{c}-0.204 \\
(0.175)\end{array}$ \\
\hline CREDIT_TO_GDP & $\begin{array}{c}0.904^{*} \\
(0.080)\end{array}$ & $\begin{array}{c}0.531 \\
(0.389)\end{array}$ & $\begin{array}{l}0.300 \\
(0.586)\end{array}$ & $\begin{array}{c}0.814 \\
(0.107)\end{array}$ & $\begin{array}{l}0.271^{* *} \\
(0.010)\end{array}$ & $\begin{array}{c}0.184 \\
(0.154)\end{array}$ & $\begin{array}{c}0.130 \\
(0.266)\end{array}$ & $\begin{array}{l}0.250^{\star \star} \\
(0.013)\end{array}$ \\
\hline $\begin{array}{l}\text { BORROWER_\&_CREDITOR_ } \\
\text { RIGHTS }\end{array}$ & $\begin{array}{c}-0.290^{* *} \\
(0.014)\end{array}$ & $\begin{array}{r}-0.264^{*} \\
(0.062)\end{array}$ & $\begin{array}{l}-0.302^{\star \star} \\
(0.024)\end{array}$ & $\begin{array}{l}-0.244^{* *} \\
(0.039)\end{array}$ & $\begin{array}{c}-0.051 \\
(0.135)\end{array}$ & $\begin{array}{c}-0.045 \\
(0.242)\end{array}$ & $\begin{array}{c}-0.054 \\
(0.155)\end{array}$ & $\begin{array}{c}-0.041 \\
(0.231)\end{array}$ \\
\hline BANKING_CONCENTRATION & $\begin{array}{l}-5.392^{* \star *} \\
(0.000)\end{array}$ & $\begin{array}{l}-4.174^{\star \star *} \\
(0.000)\end{array}$ & $\begin{array}{l}-5.011^{\star \star \star} \\
(0.000)\end{array}$ & $\begin{array}{l}-4.968^{* * *} \\
(0.000)\end{array}$ & $\begin{array}{l}-1.230^{* * *} \\
(0.000)\end{array}$ & $\begin{array}{l}-0.946^{* \star *} \\
(0.000)\end{array}$ & $\begin{array}{l}-1.146^{\text {** }} \\
(0.000)\end{array}$ & $\begin{array}{l}-1.131^{\star \star \star} \\
(0.000)\end{array}$ \\
\hline $\begin{array}{l}\text { BANKING_SECTOR_ } \\
\text { PROFITABILITY }\end{array}$ & $\begin{array}{l}3.654^{* * *} \\
(0.001)\end{array}$ & $\begin{aligned} 2.090^{*} \\
(0.065)\end{aligned}$ & $\begin{array}{l}2.939^{\star \star \star} \\
(0.010)\end{array}$ & $\begin{array}{l}3.621^{* * *} \\
(0.001)\end{array}$ & $\begin{array}{l}0.867^{\star \star \star} \\
(0.007)\end{array}$ & $\begin{array}{c}0.503 \\
(0.123)\end{array}$ & $\begin{array}{l}0.705^{\star \star} \\
(0.030)\end{array}$ & $\begin{array}{l}0.859^{\star \star \star} \\
(0.008)\end{array}$ \\
\hline $\begin{array}{l}\text { OFFSHORE_FINANCIAL_ } \\
\text { CENTER }\end{array}$ & $\begin{array}{l}-5.326^{* * *} \\
(0.001)\end{array}$ & $\begin{array}{r}-3.080^{*} \\
(0.056)\end{array}$ & $\begin{array}{c}-3.564^{\star *} \\
(0.012)\end{array}$ & $\begin{array}{l}-4.562^{* \star *} \\
(0.003)\end{array}$ & $\begin{array}{l}-1.265^{* * *} \\
(0.000)\end{array}$ & $\begin{array}{l}-0.741^{* *} \\
(0.020)\end{array}$ & $\begin{array}{l}-0.859^{\star \star \star} \\
(0.003)\end{array}$ & 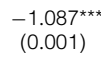 \\
\hline CONTIGUOUS & $\begin{array}{l}8.729^{* * *} \\
(0.000)\end{array}$ & $\begin{array}{l}8.873^{\star \star \star} \\
(0.000)\end{array}$ & $\begin{array}{l}7.339^{\star \star \star} \\
(0.001)\end{array}$ & $\begin{array}{l}7.581^{\star \star *} \\
(0.000)\end{array}$ & $\begin{array}{l}1.914^{* \star *} \\
(0.000)\end{array}$ & $\begin{array}{l}1.944^{\star \star \star} \\
(0.000)\end{array}$ & $\begin{array}{l}1.586^{\star \star \star} \\
(0.002)\end{array}$ & $\begin{array}{l}1.647^{\star \star \star} \\
(0.000)\end{array}$ \\
\hline COMMON_LANGUAGE & $\begin{array}{l}1.709^{* *} \\
(0.011)\end{array}$ & $\begin{array}{l}2.048^{\star \star} \\
(0.010)\end{array}$ & $\begin{array}{l}2.545^{\star \star \star} \\
(0.002)\end{array}$ & $\begin{array}{l}1.475^{\star *} \\
(0.019)\end{array}$ & $\begin{array}{c}0.241^{*} \\
(0.070)\end{array}$ & $\begin{array}{l}0.320^{* \star} \\
(0.039)\end{array}$ & $\begin{array}{l}0.438^{\star \star \star} \\
(0.009)\end{array}$ & $\begin{array}{c}0.187 \\
(0.125)\end{array}$ \\
\hline In(DISTANCE) & $\begin{array}{l}1.887^{* * *} \\
(0.006)\end{array}$ & $\begin{array}{c}1.441^{*} \\
(0.051)\end{array}$ & $\begin{array}{r}1.204^{*} \\
(0.085)\end{array}$ & $\begin{array}{l}1.691^{* *} \\
(0.012)\end{array}$ & $\begin{array}{l}0.435^{\star \star * *} \\
(0.005)\end{array}$ & $\begin{array}{l}0.330^{* \star} \\
(0.046)\end{array}$ & $\begin{array}{c}0.276^{*} \\
(0.081)\end{array}$ & $\begin{array}{l}0.389^{* * *} \\
(0.010)\end{array}$ \\
\hline MARKET_VOLATILITY & $\begin{array}{l}2.043^{* * *} \\
(0.000)\end{array}$ & $\begin{array}{l}2.060^{\star \star \star} \\
(0.000)\end{array}$ & $\begin{array}{l}2.044^{\star \star \star} \\
(0.000)\end{array}$ & $\begin{array}{l}2.057^{\star \star *} \\
(0.000)\end{array}$ & $\begin{array}{l}0.515^{\star \star \star} \\
(0.000)\end{array}$ & $\begin{array}{l}0.520^{\star \star \star} \\
(0.000)\end{array}$ & $\begin{array}{l}0.516^{\star \star \star} \\
(0.000)\end{array}$ & $\begin{array}{l}0.519^{\star \star \star} \\
(0.000)\end{array}$ \\
\hline
\end{tabular}


TABLE 7 (continued)

Risk and Foreign Regulation and Supervision Stringency

Panel A. BHC Risk and Host-Country Regulation and Supervision

\begin{tabular}{|c|c|c|c|c|c|c|c|c|}
\hline \multirow[b]{2}{*}{ Variable } & \multicolumn{4}{|c|}{ VAR } & \multicolumn{4}{|c|}{$\triangle$ COVAR } \\
\hline & 1 & 2 & 3 & 4 & 5 & 6 & 7 & 8 \\
\hline In(ASSETS) & $\begin{array}{c}0.341^{*} \\
(0.060)\end{array}$ & $\begin{array}{c}0.109 \\
(0.560)\end{array}$ & $\begin{array}{c}0.214 \\
(0.255)\end{array}$ & $\begin{array}{c}0.278 \\
(0.118)\end{array}$ & $\begin{array}{l}0.117^{\star * *} \\
(0.005)\end{array}$ & $\begin{array}{c}0.063 \\
(0.131)\end{array}$ & $\begin{array}{c}0.088^{* *} \\
(0.041)\end{array}$ & $\begin{array}{l}0.102^{\star \star} \\
(0.011)\end{array}$ \\
\hline LEVERAGE & $\begin{array}{l}0.136^{\star \star \star} \\
(0.000)\end{array}$ & $\begin{array}{l}0.142^{\star \star \star} \\
(0.000)\end{array}$ & $\begin{array}{l}0.123^{\star \star \star} \\
(0.000)\end{array}$ & $\begin{array}{l}0.126^{* * *} \\
(0.000)\end{array}$ & $\begin{array}{l}0.021^{* \star *} \\
(0.000)\end{array}$ & $\begin{array}{l}0.022^{* * *} \\
(0.001)\end{array}$ & $\begin{array}{l}0.018^{\star \star \star} \\
(0.003)\end{array}$ & $\begin{array}{l}0.019^{\star \star \star} \\
(0.001)\end{array}$ \\
\hline FOREIGN_ASSETS_PCT & $\begin{array}{c}0.091 \\
(0.962)\end{array}$ & $\begin{array}{c}-0.266 \\
(0.900)\end{array}$ & $\begin{array}{c}0.422 \\
(0.857)\end{array}$ & $\begin{array}{c}0.032 \\
(0.986)\end{array}$ & $\begin{array}{c}-0.117 \\
(0.821)\end{array}$ & $\begin{array}{c}-0.200 \\
(0.717)\end{array}$ & $\begin{array}{c}-0.037 \\
(0.950)\end{array}$ & $\begin{array}{c}-0.131 \\
(0.793)\end{array}$ \\
\hline INCOME_MIX & $\begin{array}{c}0.058 \\
(0.666)\end{array}$ & $\begin{array}{c}-0.178 \\
(0.202)\end{array}$ & $\begin{array}{c}-0.122 \\
(0.313)\end{array}$ & $\begin{array}{c}0.044 \\
(0.725)\end{array}$ & $\begin{array}{c}-0.002 \\
(0.949)\end{array}$ & $\begin{array}{r}-0.057^{\star} \\
(0.074)\end{array}$ & $\begin{array}{c}-0.043 \\
(0.116)\end{array}$ & $\begin{array}{c}-0.005 \\
(0.853)\end{array}$ \\
\hline MARKET_TO_BOOK & $\begin{array}{c}-0.054 \\
(0.643)\end{array}$ & $\begin{array}{c}0.022 \\
(0.868)\end{array}$ & $\begin{array}{c}0.019 \\
(0.883)\end{array}$ & $\begin{array}{c}-0.010 \\
(0.926)\end{array}$ & $\begin{array}{c}0.036 \\
(0.221)\end{array}$ & $\begin{array}{c}0.054 \\
(0.119)\end{array}$ & $\begin{array}{c}0.053 \\
(0.121)\end{array}$ & $\begin{array}{c}0.046 \\
(0.100)\end{array}$ \\
\hline DEPOSITS_PCT & $\begin{array}{c}-4.061^{\star \star \star} \\
(0.002)\end{array}$ & $\begin{array}{c}-5.072^{\star \star \star} \\
(0.000)\end{array}$ & $\begin{array}{c}-4.564^{\star \star \star} \\
(0.001)\end{array}$ & $\begin{array}{c}-3.785^{\star \star \star} \\
(0.002)\end{array}$ & $\begin{array}{c}-0.766^{* *} \\
(0.010)\end{array}$ & $\begin{array}{c}-1.001^{\star \star \star} \\
(0.004)\end{array}$ & $\begin{array}{c}-0.881^{\star \star \star} \\
(0.009)\end{array}$ & $\begin{array}{c}-0.702^{\star \star \star} \\
(0.005)\end{array}$ \\
\hline $\begin{array}{l}\text { No. of obs. } \\
\text { Adj. } R^{2}\end{array}$ & $\begin{array}{l}1,502 \\
0.53\end{array}$ & $\begin{array}{l}1,502 \\
0.51\end{array}$ & $\begin{array}{l}1,502 \\
0.52\end{array}$ & $\begin{array}{l}1,502 \\
0.53\end{array}$ & $\begin{array}{l}1,502 \\
0.70\end{array}$ & $\begin{array}{l}1,502 \\
0.69\end{array}$ & $\begin{array}{l}1,502 \\
0.69\end{array}$ & $\begin{array}{l}1,502 \\
0.70\end{array}$ \\
\hline
\end{tabular}

Panel B. BHC Risk and Host Countries with Less versus More Stringent Regulation and Supervision than the United States

\begin{tabular}{|c|c|c|c|c|c|c|c|c|}
\hline \multirow[b]{2}{*}{ Variable } & \multicolumn{4}{|c|}{ VAR } & \multicolumn{4}{|c|}{$\triangle$ COVAR } \\
\hline & 1 & 2 & 3 & 4 & 5 & 6 & 7 & 8 \\
\hline $\begin{array}{l}\text { REGULATION_\&_SUPERVISION } \\
\text { (less stringent than } \\
\text { United States) }\end{array}$ & $\begin{array}{l}0.763^{\star \star \star} \\
(0.000)\end{array}$ & & & & $\begin{array}{l}0.177^{\star \star \star} \\
(0.000)\end{array}$ & & & \\
\hline $\begin{array}{l}\text { REGULATION_\&_SUPERVISION } \\
\text { (more stringent than } \\
\text { United States) }\end{array}$ & $\begin{array}{r}-0.517 \\
(0.650)\end{array}$ & & & & $\begin{array}{c}-0.133 \\
(0.950)\end{array}$ & & & \\
\hline $\begin{array}{l}\text { ACTIVITY_RESTRICTIONS } \\
\text { (less stringent than } \\
\text { United States) }\end{array}$ & & $\begin{array}{c}-0.011 \\
(0.955)\end{array}$ & & & & $\begin{array}{c}-0.028 \\
(0.443)\end{array}$ & & \\
\hline $\begin{array}{l}\text { ACTIVITY_RESTRICTIONS } \\
\text { (more stringent than } \\
\text { United States) }\end{array}$ & & $\begin{array}{c}-0.458 \\
(0.337)\end{array}$ & & & & $\begin{array}{c}-0.232^{\star *} \\
(0.029)\end{array}$ & & \\
\hline $\begin{array}{l}\text { CAPITAL_REGULATION } \\
\text { (less stringent than } \\
\text { United States) }\end{array}$ & & & $\begin{array}{l}0.390^{* *} \\
(0.017)\end{array}$ & & & & $\begin{array}{l}0.093^{\star \star \star} \\
(0.006)\end{array}$ & \\
\hline $\begin{array}{l}\text { CAPITAL_REGULATION } \\
\text { (more stringent than } \\
\text { United States) }\end{array}$ & & & $\begin{array}{c}-0.248 \\
(0.262)\end{array}$ & & & & $\begin{array}{c}-0.056 \\
(0.227)\end{array}$ & \\
\hline $\begin{array}{l}\text { SUPERVISORY_POWER } \\
\text { (less stringent than } \\
\text { United States) }\end{array}$ & & & & $\begin{array}{l}0.306^{\star \star \star} \\
(0.000)\end{array}$ & & & & $\begin{array}{l}0.069^{\star \star \star} \\
(0.000)\end{array}$ \\
\hline $\begin{array}{l}\text { SUPERVISORY_POWER } \\
\text { (more stringent than } \\
\text { United States) }\end{array}$ & & & & $\begin{array}{c}0.348^{*} \\
(0.052)\end{array}$ & & & & $\begin{array}{c}0.059 \\
(0.103)\end{array}$ \\
\hline Controls & Yes & Yes & Yes & Yes & Yes & Yes & Yes & Yes \\
\hline $\begin{array}{l}\text { No. of obs. } \\
\text { Adj. } R^{2}\end{array}$ & $\begin{array}{l}1,502 \\
0.53\end{array}$ & $\begin{array}{l}1,502 \\
0.51\end{array}$ & $\begin{array}{l}1,502 \\
0.54\end{array}$ & $\begin{array}{l}1,502 \\
0.53\end{array}$ & $\begin{array}{l}1,502 \\
0.70\end{array}$ & $\begin{array}{l}1,502 \\
0.70\end{array}$ & $\begin{array}{l}1,502 \\
0.71\end{array}$ & $\begin{array}{l}1,502 \\
0.70\end{array}$ \\
\hline
\end{tabular}

and a $9.8 \%$ increase in $\triangle$ COVAR relative to their mean values $(5.6 \%$ and $1.6 \%$, respectively). In both cases, the results are significant at the $1 \%$ level. ${ }^{21}$

For each risk measure, we also show the results of the individual regulation and supervision component indices. Columns $2-4$ and $6-8$ of Table 7

\footnotetext{
${ }^{21}$ Foreign market operations in weaker regulatory regimes are associated with higher BHC risk and higher contribution to systemic risk for both subsidiaries engaged in traditional activities and subsidiaries engaged in nontraditional activities (e.g., securities, insurance, asset management, or real estate). See the Supplementary Material for more details.
} 
show that the overall significantly positive association is primarily driven by CAPITAL_REGULATION and SUPERVISORY_POWER. In contrast, the effects of ACTIVITY_RESTRICTIONS are indistinguishable from 0 . The breadth of foreign activities does not reliably contribute to domestic bank risk. One possible explanation for this finding is that a wider spectrum of activities enables riskmanagement functions to effectively diversify and neutralize risk (e.g., Barth et al. (2004)).

Panel B of Table 7 further decomposes our regulation and supervision measures by distinguishing between host countries that are stricter than the United States and those that are laxer. Overall, the results in columns 1 and 5 suggest that subsidiary operations in countries with weaker regulation and supervision than the United States drive the association between lax regulatory environments and BHC risk. Columns 2-4 and 6-8 further suggest that the adverse risk consequences of regulatory arbitrage specifically arise from using foreign subsidiaries to evade more stringent home-country capital requirements and supervisory authorities.

To mitigate endogeneity and reverse-causality concerns around the relation between BHC risk and regulatory stringency in the subsidiary location, we also conduct robustness checks with IV estimations using the instruments previously discussed in Section IV.B. Because the IVs are at the country level, our analysis leverages uncollapsed panels of BHC-quarter-subsidiary country observations. Facing multiple instances per BHC-quarter (one observation for every country of exposure), we use a weighted regression approach where we weight each country exposure within a BHC-quarter proportionately to the number of reported subsidiaries by the BHC in a given country-quarter, then weight BHCquarters equally among each other. Table 8 reports the results. Notably, the estimated coefficients for REGULATION_\&_SUPERVISION retain their positive signs and remain significant at the $1 \%$ level in the weighted 2 -stage least-squares specifications.

\section{Evidence from Foreign Market Entries}

The variation in BHC exposure to regulatory stringency through foreign subsidiaries may materialize through two channels: i) within-host-country variation in regulatory stringency over time or ii) institutions changing subsidiary locations. Because the focal area of this study is regulatory arbitrage and its risk implications, the latter channel is particularly relevant..$^{22}$ To examine this issue, we look at within-BHC risk variation due to foreign market entries as a function of hostmarket regulatory stringency. For estimation purposes, we define POST_ENTRY indicator variables that equal 1 for quarters following the first report of subsidiary presence in a country, and 0 otherwise. We use several alternative window lengths around entry events: $4,8,12$, and 16 quarters. For every event, we average data

\footnotetext{
${ }^{22}$ In the Supplementary Material, we also examine the relation between BHC risk taking and country regulation and supervision by focusing on within-host-country variation in regulatory stringency. First, we examine changes in BHC risk taking following the strengthening of regulation and supervision using the implementation of Basel 2.5 as a regulatory shock. Second, we adopt an approach similar to Lamont and Polk (2002) and focus on changes in BHC risk due to changes in host countries' stringency of regulation and supervision, keeping the countries to which BHCs have exposures unchanged. We find consistent results, suggesting that BHCs decrease (increase) risk taking when host-country regulation and supervision tightens (eases).
} 
TABLE 8

Instrumental Variable Specifications

Table 8 reports coefficient estimates from instrumental variable panel regressions of U.S. bank holding company (BHC) risk on foreign banking regulation and supervision stringency and control variables. The sample is a panel of $\mathrm{BHC}-$ quarter-subsidiary country observations during the period 1995:Q1-2013:Q4 of 64 U.S. BHCs. The regressions weight country exposures within a $\mathrm{BHC}$-quarter proportionately to the number of reported subsidiaries by a $\mathrm{BHC}$ in a given country-quarter, then weight BHC-quarters equally among each other. VAR is a BHC's unconditional maximum market equity loss at the $95 \%$ confidence level on a quarterly basis. $\triangle$ COVAR measures a BHC's contribution to systemic risk and is defined as the difference between the conditional value at risk (COVAR) of the financial system conditional on an institution being in distress (95\% quantile of quarterly equity return losses) and the COVAR conditional on the median state of the institution. REGULATION_\&_SUPERVISION measures the stringency of a country's banking regulation and supervision. It is defined as the first principal component of 3 regulation and supervision indices: ACTIVITY_RESTRICTIONS, CAPITAL_REGULATION, and SUPERVISORY_POWER. NBR_REG_\&_SUP is the median of neighboring countries' REGULATION_\&_SUPERVISION using data values from the preceding survey. GLBL_REG_\&_SUP is the median of REGULATION_\&_SUPERVISION across all countries in the sample using data values from the preceding survey. NBR_ADJ_REG_\&_SUP is the difference between a country's REGULATION_\&_SUPERVISION, using data values from the preceding survey, and NBR_REG_\&_SUP. SYSTEMIC_CRISES is the number of systemic crises a country had during the 1970s and 1980s. GOVT_OWNERSHIP is the share of assets of the top 10 banks in a country owned by the government of that country in 1970. INDEPENDENT_PCT is the percentage of years since 1776 a country has been independent. We use NBR_REG_\&_SUP in columns 1 and 2; GLBL_REG_\&_SUP in columns 3 and 4; NBR_ADJ_REG_\&_SUP in columns 5 and 6; and SYSTEMIC_CRISES, GOVT_OWNERSHIP, and INDEPENDENT_PCT in columns 7 and 8, respectively, as instrumental variables for the stringency of regulation and supervision. Detailed definitions of all variables are presented in the Appendix. Control variables are the same as used in Table 7, but their coefficient estimates are omitted for brevity. We include BHC fixed effects and use robust standard errors clustered at the BHC level in all specifications. $p$-values are reported in parentheses. ${ }^{*},{ }^{\star *}$, and ${ }^{* * \star}$ indicate significance at the $10 \%, 5 \%$, and $1 \%$ levels, respectively.

IVs: SYSTEMIC_CRISES, GOVT OWNERSHIP

$\underline{\text { IV: NBR_REG_\&_SUP IV: GLBL_REG_\&_SUP IV: NBR_ADJ_REG_\&_SUP }}$ and INDEPENDENT_PCT

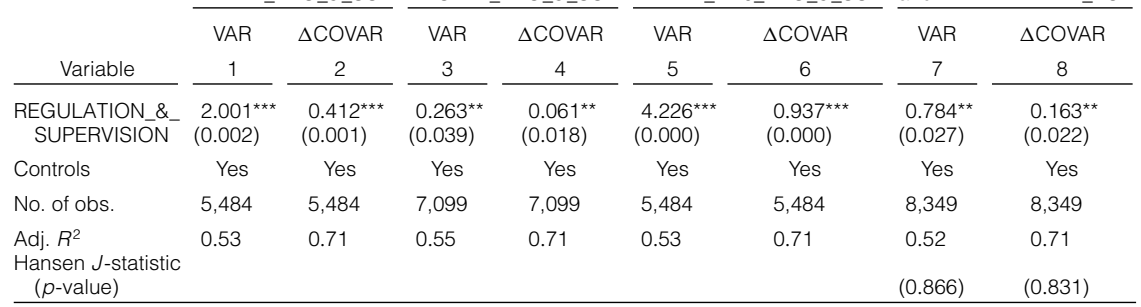

into pre-entry and post-entry observations. We then interact the POST_ENTRY indicators with country-level variables for the country of entry. We are particularly interested in the POST_ENTRY $\times$ REGULATION_\&_SUPERVISION terms and their association with BHC risk. Table 9 presents the results.

Both VAR and $\triangle$ COVAR increase in the 4 quarters following market entry when the stringency of banking regulation in host countries decreases. The increase in BHC-level risk and contribution to systemic risk is persistent, with a statistically significant relationship still observable at 8,12 , and 16 quarters following a foreign market entry. Such results are consistent with the interpretation that subsidiary locations are directly relevant for BHC risk and that their choice to operate in countries with more lax regulatory environments has both short-term and long-term risk implications.

\section{Risk-Management Quality}

Hypothesis 4 in Section II suggests that the risk effects of subsidiaries in countries with weaker regulation and supervision should be more pronounced for U.S. BHCs with a poor ability to identify, measure, monitor, and control risk. To test this conjecture, we estimate a variant of equation (2), where we include interaction terms between WRM and REGULATION_\&_SUPERVISION. Table 10 presents the results. 
TABLE 9

\section{Evidence from Foreign Country Entries}

Table 9 reports coefficient estimates from regressions of U.S. bank holding company (BHC) risk on foreign banking regulation and supervision stringency and control variables around U.S. BHCs' foreign market entries. VAR is a BHC's unconditional maximum market equity loss at the $95 \%$ confidence level on a quarterly basis. $\triangle$ COVAR measures a BHC's contribution to systemic risk and is defined as the difference between the conditional value at risk (COVAR) of the financial system conditional on an institution being in distress (95\% quantile of quarterly equity return losses) and the COVAR conditional on the median state of the institution. REGULATION_\&_SUPERVISION measures the stringency of a country's banking regulation and supervision. It is defined as the first principal component of ACTIVITY_RESTRICTIONS, CAPITAL REGULATION, and SUPERVISORY POWER. ACTIVITY RESTRICTIONS measures the stringency of a country's regulation regarding banks' involvement in securities, insurance, and real estate activities. CAPITAL_REGULATION measures the degree to which supervisory authorities in a country oversee capital at risk and the initial source of funds used to capitalize a bank. SUPERVISORY POWER measures the extent to which supervisory authorities in a country can intervene to prevent and correct problems at financial institutions. POST_ENTRY is an indicator variable that equals 1 post-entry, and 0 otherwise. For each foreign market entry, we use observation windows of $\pm 4,8,12$, or 16 quarter periods around when a BHC first reports a subsidiary in a country over the period 1995:Q1-2013:Q4. Variables are then averaged into one observation pre-entry and one observation post-entry for every event. Detailed definitions of all variables are presented in the Appendix. We include BHC fixed effects and use robust standard errors clustered at the BHC level in all specifications. $p$-values are reported in parentheses. ${ }^{*},{ }^{* *}$, and ${ }^{* * *}$ indicate significance at the $10 \%, 5 \%$, and $1 \%$ levels, respectively.

\begin{tabular}{|c|c|c|c|c|c|c|c|c|}
\hline \multirow{3}{*}{ Variable } & \multicolumn{2}{|c|}{ +/-4 Quarters } & \multicolumn{2}{|c|}{$+/-8$ Quarters } & \multicolumn{2}{|c|}{$+/-12$ Quarters } & \multicolumn{2}{|c|}{$+/-16$ Quarters } \\
\hline & VAR & $\triangle$ COVAR & VAR & $\triangle$ COVAR & VAR & $\triangle$ COVAR & VAR & $\triangle$ COVAR \\
\hline & 1 & 2 & 3 & 4 & 5 & 6 & 7 & 8 \\
\hline POST_ENTRY & $\begin{array}{c}0.463 \\
(0.477)\end{array}$ & $\begin{array}{c}0.092 \\
(0.486)\end{array}$ & $\begin{array}{c}0.624 \\
(0.249)\end{array}$ & $\begin{array}{c}0.048 \\
(0.740)\end{array}$ & $\begin{array}{l}-0.211 \\
(0.760)\end{array}$ & $\begin{array}{l}-0.186 \\
(0.442)\end{array}$ & $\begin{array}{l}-0.117 \\
(0.842)\end{array}$ & $\begin{array}{c}-0.139 \\
(0.482)\end{array}$ \\
\hline $\begin{array}{l}\text { POST_ENTRY } \times \text { REGULATION_ } \\
\text { \&_SUPERVISION }\end{array}$ & $\begin{array}{l}0.108^{* \star *} \\
(0.001)\end{array}$ & $\begin{array}{l}0.024^{\star \star \star} \\
(0.001)\end{array}$ & $\begin{array}{l}0.091^{\star \star \star} \\
(0.003)\end{array}$ & $\begin{array}{l}0.019^{* \star \star} \\
(0.005)\end{array}$ & $\begin{array}{l}0.086^{\star \star \star} \\
(0.005)\end{array}$ & $\begin{array}{l}0.019^{* \star \star} \\
(0.006)\end{array}$ & $\begin{array}{c}0.078^{\star \star} \\
(0.010)\end{array}$ & $\begin{array}{l}0.017^{\star \star} \\
(0.014)\end{array}$ \\
\hline POST_ENTRY $\times \ln ($ GDP $)$ & $\begin{array}{l}-0.127^{\star \star \star} \\
(0.000)\end{array}$ & $\begin{array}{l}-0.023^{\star \star \star} \\
(0.003)\end{array}$ & $\begin{array}{r}-0.091^{\star} \\
(0.050)\end{array}$ & $\begin{array}{l}-0.013 \\
(0.177)\end{array}$ & $\begin{array}{r}-0.067^{\star} \\
(0.071)\end{array}$ & $\begin{array}{l}-0.008 \\
(0.384)\end{array}$ & $\begin{array}{r}-0.049^{\star} \\
(0.086)\end{array}$ & $\begin{array}{c}-0.006 \\
(0.446)\end{array}$ \\
\hline POST_ENTRY $\times$ GDPG & $\begin{array}{c}-0.045 \\
(0.914)\end{array}$ & $\begin{array}{c}0.078 \\
(0.375)\end{array}$ & $\begin{array}{c}-0.153 \\
(0.693)\end{array}$ & $\begin{array}{c}0.050 \\
(0.554)\end{array}$ & $\begin{array}{l}-0.323 \\
(0.521)\end{array}$ & $\begin{array}{c}0.000 \\
(0.999)\end{array}$ & $\begin{array}{l}-0.440 \\
(0.476)\end{array}$ & $\begin{array}{c}-0.033 \\
(0.787)\end{array}$ \\
\hline $\begin{array}{l}\text { POST_ENTRY } \times \text { GDPG } \\
\text { CORRELATION }\end{array}$ & $\begin{array}{r}-0.286^{*} \\
(0.067)\end{array}$ & $\begin{array}{r}-0.059^{\star} \\
(0.071)\end{array}$ & $\begin{array}{l}-0.293^{\star \star} \\
(0.042)\end{array}$ & $\begin{array}{l}-0.061^{* *} \\
(0.045)\end{array}$ & $\begin{array}{l}-0.356^{\star \star} \\
(0.025)\end{array}$ & $\begin{array}{l}-0.083^{\star *} \\
(0.040)\end{array}$ & $\begin{array}{r}-0.310^{\star} \\
(0.060)\end{array}$ & $\begin{array}{r}-0.069^{\star} \\
(0.086)\end{array}$ \\
\hline POST_ENTRY $\times$ In (GDPPC) & $\begin{array}{l}0.156^{\star \star} \\
(0.027)\end{array}$ & $\begin{array}{l}0.032^{\star \star} \\
(0.034)\end{array}$ & $\begin{array}{c}0.073 \\
(0.343)\end{array}$ & $\begin{array}{c}0.013 \\
(0.478)\end{array}$ & $\begin{array}{c}0.085 \\
(0.267)\end{array}$ & $\begin{array}{c}0.017 \\
(0.340)\end{array}$ & $\begin{array}{c}0.053 \\
(0.429)\end{array}$ & $\begin{array}{c}0.008 \\
(0.599)\end{array}$ \\
\hline $\begin{array}{l}\text { POST_ENTRY } \times \text { BILATERAL_ } \\
\text { TRADE }\end{array}$ & $\begin{array}{c}0.101 \\
(0.645)\end{array}$ & $\begin{array}{c}0.013 \\
(0.786)\end{array}$ & $\begin{array}{c}0.125 \\
(0.506)\end{array}$ & $\begin{array}{c}0.021 \\
(0.666)\end{array}$ & $\begin{array}{c}-0.099 \\
(0.583)\end{array}$ & $\begin{array}{l}-0.046 \\
(0.345)\end{array}$ & $\begin{array}{c}-0.076 \\
(0.640)\end{array}$ & $\begin{array}{l}-0.036 \\
(0.366)\end{array}$ \\
\hline $\begin{array}{l}\text { POST_ENTRY } \times \text { COUNTRY } \\
\text { GOVERNANCE }\end{array}$ & $\begin{array}{c}-0.090 \\
(0.267)\end{array}$ & $\begin{array}{c}-0.022 \\
(0.259)\end{array}$ & $\begin{array}{c}-0.033 \\
(0.750)\end{array}$ & $\begin{array}{l}-0.004 \\
(0.863)\end{array}$ & $\begin{array}{l}-0.028 \\
(0.795)\end{array}$ & $\begin{array}{l}-0.003 \\
(0.916)\end{array}$ & $\begin{array}{c}0.009 \\
(0.931)\end{array}$ & $\begin{array}{l}0.007 \\
(0.758)\end{array}$ \\
\hline $\begin{array}{l}\text { POST_ENTRY } \times \text { CREDIT_ } \\
\text { TO_GDP }\end{array}$ & $\begin{array}{l}0.145^{\star *} \\
(0.032)\end{array}$ & $\begin{array}{l}0.036^{\star \star} \\
(0.017)\end{array}$ & $\begin{array}{l}0.127^{\star \star} \\
(0.040)\end{array}$ & $\begin{array}{l}0.029^{\star \star} \\
(0.013)\end{array}$ & $\begin{array}{l}0.117^{\star} \\
(0.066)\end{array}$ & $\begin{array}{l}0.029^{\star \star} \\
(0.037)\end{array}$ & $\begin{array}{l}0.095 \\
(0.105)\end{array}$ & $\begin{array}{c}0.025^{\star} \\
(0.066)\end{array}$ \\
\hline $\begin{array}{l}\text { POST_ENTRY } \times \text { BORROWER_ } \\
\text { \&_CREDITOR_RIGHTS }\end{array}$ & $\begin{array}{c}-0.034^{*} \\
(0.072)\end{array}$ & $\begin{array}{c}-0.009^{\star} \\
(0.051)\end{array}$ & $\begin{array}{l}-0.036^{\star \star \star} \\
(0.002)\end{array}$ & $\begin{array}{l}-0.009^{\star \star \star} \\
(0.001)\end{array}$ & $\begin{array}{l}-0.029^{\star \star \star} \\
(0.009)\end{array}$ & $\begin{array}{l}-0.007^{\star \star} \\
(0.011)\end{array}$ & $\begin{array}{l}-0.028^{\star \star \star} \\
(0.005)\end{array}$ & $\begin{array}{l}-0.007^{\star \star \star} \\
(0.004)\end{array}$ \\
\hline $\begin{array}{l}\text { POST_ENTRY } \times \text { BANKING_ } \\
\text { CONCENTRATION }\end{array}$ & $\begin{array}{l}-0.583^{\star \star \star} \\
(0.001)\end{array}$ & $\begin{array}{l}-0.121^{\star \star \star} \\
(0.001)\end{array}$ & $\begin{array}{l}-0.421^{\star \star \star} \\
(0.006)\end{array}$ & $\begin{array}{l}-0.067^{\star \star \star} \\
(0.009)\end{array}$ & $\begin{array}{l}-0.167 \\
(0.200)\end{array}$ & $\begin{array}{c}-0.013 \\
(0.638)\end{array}$ & $\begin{array}{l}-0.056 \\
(0.541)\end{array}$ & $\begin{array}{c}0.003 \\
(0.892)\end{array}$ \\
\hline $\begin{array}{l}\text { POST_ENTRY } \times \text { BANKING } \\
\text { SECTOR_PROFITABILITY }\end{array}$ & $\begin{array}{l}0.972^{* \star *} \\
(0.000)\end{array}$ & $\begin{array}{l}0.175^{\star \star \star} \\
(0.000)\end{array}$ & $\begin{array}{l}0.629^{\star \star} \\
(0.015)\end{array}$ & $\begin{array}{l}0.122^{* \star} \\
(0.016)\end{array}$ & $\begin{array}{l}0.650^{* *} \\
(0.014)\end{array}$ & $\begin{array}{l}0.161^{\star \star} \\
(0.010)\end{array}$ & $\begin{array}{l}0.695^{\star \star} \\
(0.024)\end{array}$ & $\begin{array}{l}0.164^{\star \star} \\
(0.020)\end{array}$ \\
\hline $\begin{array}{l}\text { POST_ENTRY } \times \text { OFFSHORE_ } \\
\text { FINANCIAL_CENTER }\end{array}$ & $\begin{array}{l}-0.596^{\star \star \star} \\
(0.000)\end{array}$ & $\begin{array}{l}-0.104^{\star \star \star} \\
(0.002)\end{array}$ & $\begin{array}{l}-0.348^{* \star} \\
(0.034)\end{array}$ & $\begin{array}{c}-0.045 \\
(0.182)\end{array}$ & $\begin{array}{c}-0.210 \\
(0.120)\end{array}$ & $\begin{array}{c}-0.021 \\
(0.562)\end{array}$ & $\begin{array}{c}-0.122 \\
(0.205)\end{array}$ & $\begin{array}{l}-0.008 \\
(0.769)\end{array}$ \\
\hline POST_ENTRY $\times$ CONTIGUOUS & $\begin{array}{c}0.493 \\
(0.141)\end{array}$ & $\begin{array}{c}0.072 \\
(0.259)\end{array}$ & $\begin{array}{c}0.349 \\
(0.217)\end{array}$ & $\begin{array}{c}0.046 \\
(0.347)\end{array}$ & $\begin{array}{c}0.444^{*} \\
(0.061)\end{array}$ & $\begin{array}{l}0.096^{\star \star} \\
(0.034)\end{array}$ & $\begin{array}{c}0.288 \\
(0.128)\end{array}$ & $\begin{array}{c}0.067^{\star} \\
(0.084)\end{array}$ \\
\hline $\begin{array}{l}\text { POST_ENTRY } \times \text { COMMON_} \\
\text { LANGUAGE }\end{array}$ & $\begin{array}{c}0.062 \\
(0.502)\end{array}$ & $\begin{array}{c}0.025 \\
(0.256)\end{array}$ & $\begin{array}{c}0.099 \\
(0.142)\end{array}$ & $\begin{array}{c}0.027 \\
(0.105)\end{array}$ & $\begin{array}{c}0.052 \\
(0.348)\end{array}$ & $\begin{array}{c}0.018 \\
(0.242)\end{array}$ & $\begin{array}{c}0.063 \\
(0.295)\end{array}$ & $\begin{array}{c}0.018 \\
(0.265)\end{array}$ \\
\hline POST_ENTRY $\times$ In(DISTANCE) & $\begin{array}{r}0.179^{*} \\
(0.070)\end{array}$ & $\begin{array}{r}0.027^{\star} \\
(0.085)\end{array}$ & $\begin{array}{r}0.142^{\star} \\
(0.096)\end{array}$ & $\begin{array}{c}0.020 \\
(0.143)\end{array}$ & $\begin{array}{r}0.136^{*} \\
(0.054)\end{array}$ & $\begin{array}{r}0.025^{\star} \\
(0.072)\end{array}$ & $\begin{array}{r}0.100^{*} \\
(0.064)\end{array}$ & $\begin{array}{c}0.020^{*} \\
(0.082)\end{array}$ \\
\hline MARKET_VOLATILITY & $\begin{array}{l}2.964^{\star \star \star} \\
(0.000)\end{array}$ & $\begin{array}{l}0.698^{\star \star \star} \\
(0.000)\end{array}$ & $\begin{array}{l}3.237^{\star \star \star} \\
(0.000)\end{array}$ & $\begin{array}{l}0.753^{* \star \star} \\
(0.000)\end{array}$ & $\begin{array}{l}3.310^{\star \star \star *} \\
(0.000)\end{array}$ & $\begin{array}{l}0.774^{\star \star \star \star} \\
(0.000)\end{array}$ & $\begin{array}{l}3.292^{\star \star \star} \\
(0.000)\end{array}$ & $\begin{array}{l}0.778^{\star \star \star} \\
(0.000)\end{array}$ \\
\hline In(ASSETS) & $\begin{array}{c}0.181 \\
(0.125)\end{array}$ & $\begin{array}{l}0.077^{\star \star \star} \\
(0.003)\end{array}$ & $\begin{array}{c}0.141 \\
(0.353)\end{array}$ & $\begin{array}{l}0.065^{\star \star} \\
(0.037)\end{array}$ & $\begin{array}{c}0.173 \\
(0.237)\end{array}$ & $\begin{array}{l}0.076^{\star \star \star} \\
(0.010)\end{array}$ & $\begin{array}{c}0.181 \\
(0.206)\end{array}$ & $\begin{array}{l}0.067^{\star \star \star} \\
(0.006)\end{array}$ \\
\hline LEVERAGE & $\begin{array}{c}0.034 \\
(0.408)\end{array}$ & $\begin{array}{c}0.011 \\
(0.269)\end{array}$ & $\begin{array}{c}0.046 \\
(0.275)\end{array}$ & $\begin{array}{c}0.012 \\
(0.244)\end{array}$ & $\begin{array}{c}0.050 \\
(0.279)\end{array}$ & $\begin{array}{c}0.015 \\
(0.200)\end{array}$ & $\begin{array}{c}0.040 \\
(0.327)\end{array}$ & $\begin{array}{c}0.012 \\
(0.261)\end{array}$ \\
\hline FOREIGN_ASSETS_PCT & $\begin{array}{c}1.991 \\
(0.464)\end{array}$ & $\begin{array}{c}0.288 \\
(0.628)\end{array}$ & $\begin{array}{c}1.374 \\
(0.604)\end{array}$ & $\begin{array}{c}0.062 \\
(0.912)\end{array}$ & $\begin{array}{c}0.495 \\
(0.839)\end{array}$ & $\begin{array}{c}-0.225 \\
(0.702)\end{array}$ & $\begin{array}{c}0.392 \\
(0.860)\end{array}$ & $\begin{array}{c}-0.203 \\
(0.699)\end{array}$ \\
\hline INCOME_MIX & $\begin{array}{c}0.024 \\
(0.875)\end{array}$ & $\begin{array}{c}-0.021 \\
(0.525)\end{array}$ & $\begin{array}{c}0.080 \\
(0.546)\end{array}$ & $\begin{array}{c}-0.009 \\
(0.713)\end{array}$ & $\begin{array}{c}0.084 \\
(0.512)\end{array}$ & $\begin{array}{c}-0.006 \\
(0.803)\end{array}$ & $\begin{array}{c}0.067 \\
(0.620)\end{array}$ & $\begin{array}{c}-0.006 \\
(0.787)\end{array}$ \\
\hline MARKET_TO_BOOK & $\begin{array}{l}0.285^{\star \star \star} \\
(0.005)\end{array}$ & $\begin{array}{l}0.070^{\star \star \star} \\
(0.006)\end{array}$ & $\begin{array}{r}0.230^{*} \\
(0.078)\end{array}$ & $\begin{array}{c}0.060^{\star \star} \\
(0.044)\end{array}$ & $\begin{array}{c}0.222^{\star} \\
(0.085)\end{array}$ & $\begin{array}{c}0.060^{\star *} \\
(0.036)\end{array}$ & $\begin{array}{c}0.222^{\star} \\
(0.066)\end{array}$ & $\begin{array}{l}0.055^{\star \star} \\
(0.026)\end{array}$ \\
\hline DEPOSITS_PCT & $\begin{array}{c}-1.689 \\
(0.171)\end{array}$ & $\begin{array}{c}-0.077 \\
(0.761)\end{array}$ & $\begin{array}{c}-1.246 \\
(0.145)\end{array}$ & $\begin{array}{c}0.038 \\
(0.816)\end{array}$ & $\begin{array}{c}-0.666 \\
(0.476)\end{array}$ & $\begin{array}{c}0.217 \\
(0.285)\end{array}$ & $\begin{array}{c}-0.499 \\
(0.598)\end{array}$ & $\begin{array}{c}0.250 \\
(0.166)\end{array}$ \\
\hline $\begin{array}{l}\text { No. of obs. } \\
\text { Adj. } R^{2}\end{array}$ & $\begin{array}{l}2,116 \\
0.80\end{array}$ & $\begin{array}{l}2,116 \\
0.90\end{array}$ & $\begin{array}{l}2,116 \\
0.86\end{array}$ & $\begin{array}{l}2,116 \\
0.93\end{array}$ & $\begin{array}{l}2,116 \\
0.88\end{array}$ & $\begin{array}{l}2,116 \\
0.95\end{array}$ & $\begin{array}{l}2,116 \\
0.89\end{array}$ & $\begin{array}{l}2,116 \\
0.96\end{array}$ \\
\hline
\end{tabular}


TABLE 10

Risk and Risk-Management Quality

Table 10 reports coefficient estimates from panel regressions of U.S. bank holding company (BHC) risk on foreign banking regulation and supervision stringency, interactions with BHC risk-management quality, and control variables. The sample is a panel of BHC-quarter observations during the period 1995:Q1-2013:Q4 of 64 U.S. BHCs. VAR is a BHC's unconditional maximum market equity loss at the $95 \%$ confidence level on a quarterly basis. $\triangle$ COVAR measures a BHC's contribution to systemic risk and is defined as the difference between the conditional value at risk (COVAR) of the financial system conditional on an institution being in distress ( $95 \%$ quantile of quarterly equity return losses) and the COVAR conditional on the median state of the institution. REGULATION_\&_SUPERVISION measures the stringency of a country's banking regulation and supervision. It is defined as the first principal component of ACTIVITY_RESTRICTIONS, CAPITAL REGULATION, and SUPERVISORY POWER. ACTIVITY RESTRICTIONS measures the stringency of a country's regulation regarding banks' involvement in securities, insurance, and real estate activities. CAPITAL_REGULATION measures the degree to which supervisory authorities in a country oversee capital at risk and the initial source of funds used to capitalize a bank. SUPERVISORY_POWER measures the extent to which supervisory authorities in a country can intervene to prevent and correct problems at financial institutions. WRM is an indicator variable for weak risk-management practices at a given $\mathrm{BHC}$ during a quarter. WRM equals 1 if a $\mathrm{BHC}$ has a Federal Reserve System risk-management rating (ranging from 1 to 5 ) that is greater than or equal to 3 , and 0 otherwise. RMI measures the organizational strength and independence of the risk-management function at a given BHC during a year (Ellul and Yerramilli (2013)). Subsidiary count weights within a BHC-quarter are used to "collapse" BHC-quarter-subsidiary country observations to the BHC-quarter level. Detailed definitions of all variables are presented in the Appendix. Control variables are the same as used in Table 7, but their coefficient estimates are omitted for brevity. We include BHC fixed effects and use robust standard errors clustered at the BHC level in all specifications. $p$-values are reported in parentheses. ${ }^{*},{ }^{* *}$, and ${ }^{* \star *}$ indicate significance at the $10 \%, 5 \%$, and $1 \%$ levels, respectively.

\begin{tabular}{|c|c|c|c|c|}
\hline \multirow[b]{2}{*}{ Variable } & \multicolumn{2}{|c|}{ VAR } & \multicolumn{2}{|c|}{$\triangle$ COVAR } \\
\hline & 1 & 2 & 3 & 4 \\
\hline REGULATION_\&_SUPERVISION & $\begin{array}{l}0.783^{\star \star \star} \\
(0.000)\end{array}$ & $\begin{array}{l}0.523^{\star \star \star} \\
(0.000)\end{array}$ & $\begin{array}{l}0.184^{\star \star \star} \\
(0.000)\end{array}$ & $\begin{array}{l}0.123^{\star * \star} \\
(0.000)\end{array}$ \\
\hline REGULATION_\&_SUPERVISION $\times$ WRM & $\begin{array}{l}0.414^{\star \star \star} \\
(0.000)\end{array}$ & & $\begin{array}{l}0.065^{\star \star \star} \\
(0.006)\end{array}$ & \\
\hline WRM & $\begin{array}{c}0.647 \\
(0.102)\end{array}$ & & $\begin{array}{l}0.222^{\star \star \star} \\
(0.003)\end{array}$ & \\
\hline REGULATION_\&_SUPERVISION $\times$ RMI & & $\begin{array}{l}0.126^{\star \star} \\
(0.034)\end{array}$ & & $\begin{array}{c}0.037^{\star \star} \\
(0.018)\end{array}$ \\
\hline RMI & & $\begin{array}{c}-0.187 \\
(0.776)\end{array}$ & & $\begin{array}{c}-0.057 \\
(0.729)\end{array}$ \\
\hline Controls & Yes & Yes & Yes & Yes \\
\hline $\begin{array}{l}\text { No. of obs. } \\
\text { Adj. } R^{2}\end{array}$ & $\begin{array}{l}1,481 \\
0.53\end{array}$ & $\begin{array}{l}1,290 \\
0.53\end{array}$ & $\begin{array}{l}1,481 \\
0.70\end{array}$ & $\begin{array}{l}1,290 \\
0.69 \\
\end{array}$ \\
\hline
\end{tabular}

Columns 1 and 3 of Table 10 indicate that the increased risk associated with operations in countries with weaker regulatory environments is largely concentrated in BHCs with weak risk-management functions and internal control systems. The results are directionally similar for both stand-alone BHC risk and contribution to systemic risk. More specifically, decreasing the stringency of the regulatory environment by 1 standard deviation and contemporaneously switching the quality of BHC risk management from "strong" to "weak" increases VAR and $\triangle$ COVAR by $6.4 \%$ and $3.6 \%$, respectively, relative to their means. Columns 2 and 4 show that our results are also robust to using RMI instead of WRM as the measure of risk-management quality. In all cases, results are significant at least at the $5 \%$ level.

\section{Policy Discussion}

Our study is relevant to the policy discussion around international regulatory and supervisory coordination following the global financial crisis. Recent research highlights a fairly low degree of cooperation in banking supervision and regulation across countries (e.g., Beck, Silva-Buston, and Wagner (2018)) and 
the increased political pressure regarding the participation of the United States in international regulatory coordination (e.g., Temesvary (2018)).

Cross-border banking supervision and regulation is understood to face a so-called "financial trilemma" or the incompatibility of 3 policy objectives: maintaining global financial stability; pursuing cross-border financial integration; and maintaining national regulation, supervision, and resolution authority (Schoenmaker (2011), (2013)). As a result, national authorities adopt supervisory cooperation models with the goal of maximizing national welfare, where the spectrum of frameworks lies along a continuum of increasing loss of sovereignty (Beck and Wagner (2016)). At one end of the cooperation spectrum is a "territorial approach," whereby each unit of a global banking organization is regulated and supervised according to local standards and without regard to any cross-border considerations. At the other end is a "universal approach" with legally binding supervisory frameworks, centralized decision making, and loss of sovereignty. In practice, countries adopt intermediate models of cooperation.

Our results highlight a significant drawback with the territorial approach. Specifically, global banks can undermine domestic regulation and supervision by "importing" risks through regulatory arbitrage. Such results suggest the need for converging on internationally accepted principles and practices in banking regulation so as to reduce regulatory arbitrage opportunities. In the absence of an overarching international financial-sector regulator, which remains unlikely, improved international coordination can be a viable way to address cross-country differences. Specifically, a core set of regulatory principles agreed upon and implemented by national regulators across jurisdictions might be sufficient to reduce regulatory arbitrage, even if specific national implementations of the principles vary to some extent. ${ }^{23}$ Overall, our findings are consistent with the post-crisis approaches of the FSB and BCBS in terms of improved international coordination.

Our results also highlight that the increased risk from cross-border regulatory arbitrage is heightened for institutions with weak internal controls and risk management. To that effect, tailoring supervision and regulation for global banks based on individual bank characteristics (e.g., risk management, governance, and controls) could support financial stability even in the presence of cross-border regulatory differences. Compared to "one-size-fits-all" policies, regulatory approaches that are customized to banks' individual characteristics could be a more efficient way to mitigate the stand-alone and systemic risk impact of banking organizations' regulation-induced activity locations. Specifically, tailored policies could reduce the deadweight costs of internationally harmonized supervision and regulation due to country heterogeneity with regard to legal and regulatory systems or exposure to bank-failure costs.

\footnotetext{
${ }^{23}$ As discussed by Acharya, Wachtel, and Walter (2009), this set of principles is necessarily broad and could include among other things: providing long-term incentives to senior management and risktaking employees; fair pricing of explicit government guarantees; standards for transparency and accounting of off-balance-sheet activities; centralized clearing for large over-the-counter derivative markets; imposition of a systemic risk "tax" on large, systemically important financial institutions; robust design of lender-of-last-resort facilities; agreement on a set of procedures to stem systemic crises when they arise.
} 


\section{Conclusion}

Many have expressed concerns that the lack of a harmonized regulatory framework across major jurisdictions is bound to lead to competitive distortions among financial institutions and encourage regulatory arbitrage. Others have emphasized that any actions on such concerns should also be balanced with the benefits of flexibility in policy design tailored to individual country banking sectors.

With such issues in mind, this study examines whether cross-country differences in bank regulation and supervision play a role in the choice of subsidiary locations for U.S. BHCs and whether such choices have implications for institution-specific risk and systemic risk in the United States. Consistent with regulatory arbitrage, we find that BHCs are more likely to operate subsidiaries in countries with more lax regulatory environments (defined as fewer activity restrictions, less stringent capital requirements, and weaker supervision). We also find that BHCs with more subsidiary operations in countries with weaker regulatory environments have higher firm-level risk and positively contribute to systemic risk. Overall, our results are consistent with a "race to the bottom" explanation for regulatory arbitrage. Importantly, our analysis also highlights the importance of $\mathrm{BHC}$ risk-management functions in both location choices and risk outcomes.

Our findings have potentially important policy implications at the national and international levels. The cross-border transmission and propagation of financial shocks during the 2008-2009 global financial crisis demonstrated that enhanced coordination in international supervision and regulation is important. In an increasingly interconnected global financial world, the lack of a level regulatory and supervisory playing field creates opportunities for cross-border arbitrage that may result in greater system-wide risks.

\section{Appendix. Variable Definitions and Sources}

ACTIVITY_RESTRICTIONS: A measure of the stringency of regulation regarding banks' involvement in securities, insurance, and real estate activities. The index ranges from 3 to 12 and is transformed so that higher values indicate weaker stringency. Source: Barth et al. (2013).

BANKING_CONCENTRATION: The degree of the banking-industry asset concentration in the 5 largest banks of a country. Source: Barth et al. (2013).

BANKING_SECTOR_PROFITABILITY: A country's banking-sector return on equity after taxes. Source: Global Financial Development Database.

BILATERAL_TRADE: The maximum of bilateral imports and exports between the United States and a given country. Bilateral imports (exports) are calculated as the total value of imports (exports) by a given country from (to) the United States as a proportion of total imports by that country from (to) the rest of the world. Source: International Monetary Fund (IMF) Direction of Trade Statistics.

BORROWER_\&_CREDITOR_RIGHTS: An index that measures the degree to which collateral and bankruptcy laws protect the legal rights of borrowers and lenders. The index ranges from 0 to 12 . A higher score indicates stronger borrower and creditor rights. Source: World Bank's Doing Business 2015.

CAPITAL_REGULATION: A measure of the degree to which supervisory authorities oversee capital at risk and the initial source of funds used to capitalize a bank. 
The index ranges from 0 to 10 and is transformed so that higher values indicate weaker stringency. Source: Barth et al. (2013).

COMMON_LANGUAGE: An indicator variable that equals 1 if a country's official language is English, and 0 otherwise. Source: Mayer and Zignago (2011).

CONTIGUOUS: An indicator variable that equals 1 for countries that share a border with the United States, and 0 otherwise. Source: Mayer and Zignago (2011).

COUNTRY_GOVERNANCE: The simple average of 6 governance indicators: control of corruption, regulatory quality, rule of law, voice and accountability, government effectiveness, and political stability. Source: Kaufman et al. (2009).

$\triangle$ COVAR: A measure of a bank holding company's (BHC's) contribution to systemic risk, defined as the difference between the conditional value at risk (COVAR) of the financial system conditional on an institution being in distress (95\% quantile of quarterly equity return losses) and the COVAR conditional on the median state of the institution. Source: Adrian and Brunnermeier (2016).

CREDIT_TO_GDP: A country's private credit by deposit money banks and other financial institutions as a share of gross domestic product (GDP). Source: Global Financial Development Database.

DEPOSITS_PCT: The ratio of deposits to total BHC assets. Source: FR Y-9C.

FOREIGN_ASSETS_PCT: Total selected foreign assets divided by total BHC assets. Source: Bank Holding Company Performance Reports (BHCPR) and FR Y-9C.

GDPG: A country's real GDP growth. Source: World Bank Development Indicators.

GDPG_CORRELATION: The $R^{2}$ of ordinary least squares (OLS) regressions of U.S. GDP growth on a given country's GDP growth.

GLBL_REG_\&_SUP: The median of REGULATION_\&_SUPERVISION across all countries in the sample using data values from the preceding survey.

GOVT_OWNERSHIP: The share of assets of the top 10 banks in a country owned by the government of that country in 1970. Source: La Porta et al. (2002).

INCOME_MIX: The ratio of BHC noninterest income to interest income. Source: FR Y-9C.

INDEPENDENT_PCT: The percentage of years since 1776 a country has been independent.

LEVERAGE: Total BHC assets divided by total BHC equity capital. Source: FR Y-9C.

$\ln ($ ASSETS): The natural logarithm of BHC total assets. Source: FR Y-9C.

$\ln$ (DISTANCE): The natural logarithm of the distance in kilometers between New York and the most populated city in other countries. Source: Mayer and Zignago (2011).

$\ln (\mathrm{GDP})$ : The natural logarithm of a country's GDP in constant 2005 USD. Source: World Bank Development Indicators.

$\ln ($ GDPPC): The natural logarithm of a country's GDP per capita in constant 2005 USD. Source: World Bank Development Indicators.

ln(NSUB): The natural logarithm of 1 plus the total number of foreign subsidiaries a BHC reports in a country during a given year. Source: FR Y-10.

MARKET_TO_BOOK: Market value of equity divided by total BHC book value of equity. Source: FR Y-9C and Center for Research in Security Prices (CRSP). 
MARKET_VOLATILITY: The quarterly average of the standard deviation of U.S. stock returns. Source: CRSP.

NBR_ADJ_REG_\&_SUP: The difference between a country's REGULATION_\&_ SUPERVISION, using data values from the preceding survey, and NBR_REG_\&_SUP.

NBR_REG_\&_SUP: The median of neighboring countries' REGULATION_\&_ SUPERVISION using data values from the preceding survey. A country's neighbors are determined in accordance with Anderson (2003) and Charney, Colson, and Smith (2005).

OFFSHORE_FINANCIAL_CENTER: An indicator variable that equals 1 if a country is classified as an offshore financial center by the Financial Stability Board (FSB), and 0 otherwise. Source: International Monetary Fund (2000).

PRESSUB: An indicator variable that equals 1 if a BHC reports having foreign subsidiaries in a given country during a year, and 0 otherwise. Source: FR Y-10.

REGULATION_\&_SUPERVISION: A measure of a country's overall banking regulation and supervision, defined as the first principal component of ACTIVITY_RESTRICTIONS, CAPITAL_REGULATION, and SUPERVISORY_ POWER. Higher values indicate weaker regulation and supervision stringency.

RMI: The first principal component of 7 measures of BHCs' risk-management quality: i) an indicator for BHCs with a designated chief risk officer (CRO); ii) an indicator for BHCs where the CRO is an executive officer; iii) an indicator for BHCs where the CRO is among the 5 highest-paid executives; iv) CRO centrality, defined as the ratio of the CRO's total compensation to the chief executive officer's (CEO's) total compensation; v) an indicator for BHCs where at least one of the directors serving on the board's risk committee has banking experience; vi) an indicator for BHCs where the board risk committee meets more frequently during a year than the board risk committee of the average $\mathrm{BHC}$; and vii) an indicator that identifies if a BHCs' key management-level risk committee reports directly to the board of directors. The original index is transformed so that it is decreasing in the quality of a BHC's riskmanagement functions. Source: Ellul and Yerramilli (2013).

SUPERVISORY_POWER: A measure of the extent to which supervisory authorities can intervene to prevent and correct problems at financial institutions. The index ranges from 0 to 14 and is transformed so that higher values indicate weaker stringency. Source: Barth et al. (2013).

SYSTEMIC_CRISES: The number of systemic crises a country had during the 1970s and 1980s. Source: Laeven and Valencia (2013).

VAR: The unconditional maximum market equity loss at the $95 \%$ confidence level on a quarterly basis. Source: Adrian and Brunnermeier (2016).

WRM: An indicator measuring the quality of a BHC's risk management function. WRM takes a value of 1 if a BHC has a Federal Reserve System risk-management rating (ranging from 1 to 5 ) that is greater than or equal to 3 , and 0 otherwise. Source: Confidential safety and soundness supervisory reports.

\section{Supplementary Material}

Supplementary Material for this article is available at https://doi.org/10.1017/ S0022109019000267. 


\section{References}

Abiad, A., and A. Mody. "Financial Reform: What Shakes It? What Shapes It?" American Economic Review, 95 (2005), 66-88.

Acharya, V. V.; L. H. Pedersen; T. Philippon; and M. Richardson. "Measuring Systemic Risk.” Review of Financial Studies, 30 (2016), 2-47.

Acharya, V. V.; P. Wachtel; and I. Walter. "International Alignment of Financial Sector Regulation.” In Restoring Financial Stability: How to Repair a Failed System, V. V. Acharya and M. Richardson, eds. Hoboken, NJ: John Wiley \& Sons (2009).

Adrian, T., and M. Brunnermeier. "CoVaR.” American Economic Review, 106 (2016), 1705-1741.

Amihud, Y.; G. L. Delong; and A. Saunders. "The Effects of Cross-Border Bank Mergers on Bank Risk and Value." Journal of International Money and Finance, 21 (2002), 857-877.

Anderson, E. International Boundaries: A Geopolitical Atlas. New York, NY: Routledge (2003).

Barth, J. R.; G. Caprio; and R. Levine. "Bank Regulation and Supervision: What Works Best?" Journal of Financial Intermediation, 13 (2004), 205-248.

Barth, J. R.; G. Caprio; and R. Levine. "Bank Regulation and Supervision in 180 Countries from 1999 to 2011.” Journal of Financial Economic Policy, 5 (2013), 111-219.

Beck, T.; A. Demirgüç-Kunt; and R. Levine. "Bank Supervision and Corruption in Lending." Journal of Monetary Economics, 53 (2006), 2131-2163.

Beck, T.; C. Silva-Buston; and W. Wagner. "The Economics of Supranational Bank Supervision." Center for Economic Policy Research Discussion Paper No. 12764 (2018).

Beck, T., and W. Wagner. "Supranational Supervision: How Much and for Whom?" International Journal of Central Banking, 12 (2016), 221-268.

Beltratti, A., and R. M. Stulz. "The Credit Crisis around the Globe: Why Did Some Banks Perform Better?" Journal of Financial Economics, 105 (2012), 1-17.

Berger, A. N.; S. E. Ghoul; O. Guedhami; and R. A. Roman. "Internationalization and Bank Risk." Management Science, 63 (2017), 2283-2301.

Buch, C. M. "Information or Regulation: What Drives the International Activities of Commercial Banks?" Journal of Money, Credit and Banking, 35 (2003), 851-869.

Buch, C. M.; C. T. Koch; and M. Koetter. "Do Banks Benefit from Internationalization? Revisiting the Market Power-Risk Nexus." Review of Finance, 17 (2013), 1401-1435.

Buera, F. J.; A. Monge-Naranjo; and G. E. Primiceri. "Learning the Wealth of Nations." Econometrica, 79 (2011), 1-45.

Carbo-Valderde, S.; E. J. Kane; and F. Rodriguez-Fernandez. "Regulatory Arbitrage in Cross-Border Banking Mergers within the EU." Journal of Money, Credit and Banking, 44 (2012), 1609-1629.

Cetorelli, N., and L. S. Goldberg. "Global Banks and International Shock Transmission: Evidence from the Crisis." IMF Economic Review, 59 (2011), 41-76.

Charney, J.; D. Colson; and R. Smith. International Maritime Boundaries. Leiden, Netherlands: Hotei (2005).

Demirgüç-Kunt, A., and E. Detragiache. "Does Deposit Insurance Increase Banking System Stability? An Empirical Investigation.” Journal of Monetary Economics, 49 (2002), 1373-1406.

Djankov, S.; M. Caralee; and A. Shleifer. "Private Credit in 129 Countries." Journal of Financial Economics, 12 (2007), 77-99.

Ellul, A., and V. Yerramilli. "Stronger Risk Controls, Lower Risk: Evidence from U.S. Bank Holding Companies." Journal of Finance, 68 (2013), 1757-1803.

Fiechter, J.; I. Otker-Robe; A. Ilyina; M. Hsu; A. Santos; and J. Surti. "Subsidiaries or Branches: Does One Size Fit All?" International Monetary Fund Staff Discussion Note SDN/11/04 (2011).

Focarelli, D., and A. F. Pozzolo. "Where Do Banks Expand Abroad? An Empirical Analysis." Journal of Business, 78 (2005), 2435-2464.

Goldberg, L. G., and A. Saunders. "The Causes of U.S. Bank Expansion Overseas: The Case of Great Britain.” Journal of Money, Credit and Banking, 12 (1980), 630-643.

Hagendorff, J.; M. Collins; and K. Keasey. "Investor Protection and the Value Effects of Bank Merger Announcements in Europe and the US." Journal of Banking and Finance, 32 (2008), 1333-1348.

Houston, J. F.; C. Lin; and Y. Ma. "Regulatory Arbitrage and International Bank Flows." Journal of Finance, 67 (2012), 1845-1895.

International Monetary Fund. "Offshore Financial Centers.” International Monetary Fund Background Paper (2000).

Kalemli-Ozcan, S.; E. Papaioannou; and J. L. Peydró. "Financial Regulation, Financial Globalization, and the Synchronization of Economic Activity." Journal of Finance, 68 (2013), 1179-1228.

Karolyi, G. A.; J. Sedunov; and A. G. Taboada. "Cross-Border Bank Flows and Systemic Risk." Working Paper, Cornell University (2016). 
Karolyi, G. A., and A. G. Taboada. "Regulatory Arbitrage and Cross-Border Bank Acquisitions." Journal of Finance, 70 (2015), 2395-2450.

Kaufman, D.; A. Kraay; and M. Mastruzzi. "Governance Matters VIII: Aggregate and Individual Governance Indicators 1996-2008.” Policy Research Working Paper, World Bank (2009).

La Porta, R.; F. Lopez-de-Silanes; A. Shleifer; and R. Vishny. "Investor Protection and Corporate Valuation." Journal of Finance, 57 (2002), 1147-1170.

Laeven, L., and F. Valencia. "Systemic Banking Crises Database.” IMF Economic Review, 61 (2013), $225-270$.

Lamont, O. A., and C. Polk. "Does Diversification Destroy Value? Evidence from the Industry Shocks." Journal of Financial Economics, 63 (2002), 51-77.

Lin, L.; A. Mihov; L. Sanz; and D. Stoyanova. "Property Rights Institutions, Foreign Investment, and the Valuation of Multinational Firms." Journal of Financial Economics, forthcoming (2019).

Masciandaro, D., and D. Romelli. "Central Bankers as Supervisors: Do Crises Matter?" European Journal of Political Economy, 52 (2018), 120-140.

Mayer, T., and S. Zignago. "Notes on CEPII's Distances Measures: The GeoDist Database.” Working Paper, CEPII (2011).

McGuire, P., and N. Tarashev. Global Monitoring with the BIS International Banking Statistics. Working Paper, Bank for International Settlements (2008).

Mian, A. "Distance Constraints: The Limits of Foreign Lending in Poor Economies." Journal of Finance, 61 (2006), 1465-1505.

Miller, S. R., and A. Parkhe. "Patterns in the Expansion of U.S. Banks' Foreign Operations." Journal of International Business Studies, 29 (1998), 359-388.

Morrison, A. D., and L. White. "Level Playing Fields in International Financial Regulation." Journal of Finance, 64 (2009), 1099-1142.

Ongena, S.; A. Popov; and G. F. Udell. "When the Cat's Away the Mice Will Play': Does Regulation at Home Affect Bank Risk-Taking Abroad?" Journal of Financial Economics, 108 (2013), 727-750.

Persson, T., and G. Tabellini. "Democratic Capital: The Nexus of Political and Economic Change." American Economic Journal: Macroeconomics, 1 (2009), 88-126.

Rose, A. K., and M. M. Spiegel. "Offshore Financial Centres: Parasites or Symbionts?" Economic Journal, 117 (2007), 1310-1335.

Schoenmaker, D. "The Financial Trilemma.” Economics Letters, 111 (2011), 57-59.

Schoenmaker, D. Governance of International Banking: The Financial Trilemma. Oxford, UK: Oxford University Press (2013).

Sengupta, R. "Foreign Entry and Bank Competition." Journal of Financial Economics, 84 (2007), $502-528$.

Stock, J., and M. Yogo. Testing for Weak Instruments in Linear IV Regression. New York, NY: Cambridge University Press (2005), 80-108.

Strauss-Kahn, D. "Crisis Management and Policy Coordination: Do We Need a New Global Framework?" A Speech at Oesterreichische Nationalbank, Vienna. International Monetary Fund (May $15,2009)$.

Tarullo, D. Statement Before the Subcommittee on Security and International Trade and Finance, Committee on Banking, Housing, and Urban Affairs, U.S. Senate (July 20, 2010).

Temesvary, J. "The Role of Regulatory Arbitrage in U.S. Banks' International Flows: Bank-Level Evidence.” Economic Inquiry, 56 (2018), 2077-2098. 